Article

\title{
Regions Set in Stone-Delimiting and Categorizing Regions in Europe by Settlement Patterns Derived from EO-Data
}

\author{
Hannes Taubenböck*, Joachim Ferstl and Stefan Dech \\ German Aerospace Center (DLR), Earth Observation Center (EOC), German Remote Sensing Data Center (DFD), \\ Oberpfaffenhofen, Wessling 82234, Germany; joachim.ferstl@dlr.de (J.F.); stefan.dech@dlr.de (S.D.) \\ * Correspondence: hannes.taubenboeck@dlr.de
}

Academic Editors: Songnian Li, Jun Chen and Wolfgang Kainz

Received: 24 November 2016; Accepted: 15 February 2017; Published: 21 February 2017

\begin{abstract}
The spatial patterns of landscapes are complex. Highly dense urban centers are not just mirrowed in a dichotomic sense by rural environments; landscapes are a spatially variable continuum. In this logic, nation-states (or any political or administrative unit) spatially integrate different types and physical appearances of land cover. Understanding regions in the sense that similar physical characteristics may construct alternative (natural) spatial entities which may sub-divide or cross-over adminstrative boundaries allows us to overcome common map projections. However, which indicators and which regional logics define and delimit regions is conceptually vague. With this paper we aim to add an empirical study to identify regional phenomena in Europe. To do so, we take advantage of a new data set from remote sensing, the Global Urban Footprint. It features European-wide consistent spatial information on settlement patterns. We use density and distribution of settlements as indicators for delimiting regions by similar characteristics. Our methodological approach classifies urban nodes (by settlement density and size), spans an unbounded soft space by the classification of spatial connectivity between nodes (by continuous settlement) and maps territorial entities (by density around nodes); the approach is following a space of place logic. From a geographic perspective we identify uneven development across Europe. The corridor streching from England via the Benelux areas via Germany, Switzerland, France to Northern Italy is mapped as the European backbone; however, new focal areas such as, e.g., towards eastern Europe are also detected. Applying a plausibility check reveals that the proxy settlement pattern corresponds well with regional conceptions presented in other studies.
\end{abstract}

Keywords: regional phenomena; remote sensing; global urban footprint; settlement pattern; urban nodes; Europe; mega-region; urban corridor; spatial analysis

\section{Introduction}

In maps, space is constructed. The most common map representation uses political boundaries of nation-states. The arrangement of space by the nation-state or any other administrative entity spatially captures a political level of action and it is often used for comparative studies on disparities. Nevertheless, these geographical units cannot be taken for granted. Artificially constructed areas do not necessarily reflect natural units or regions understood as an associated, bounded spatial entity of similar characteristics (economic, cultural, social, physical, etc.). In consequence, these spatial representations are hiding even or uneven developments at finer or larger scales. Thus, we have to find out what and who can be aggregated to reasonable entities [1].

The academic debate termed as the "new regionalism" (e.g., cf. [2-4]) suggests the transformations of societies into new entities challenging the nation-state as the "natural economic zone" (e.g., $[5,6])$. 
With spatial conceptions such as mega-regions, mega-city regions, global cities, (cross-border) city- or metropolitan regions, urban corridors or large urban morphological zones, a patchwork of (overlapping, and sometimes even contradicting) regional maps, which deviate from the common national or other administrative arrangements, have been created (e.g., [7-16]). Concrete conceptions for Europe such as the Blue [17], the Yellow or the Sunbelt Banana (e.g., [18]), the 'red octopus' [19], the 'blue star' [20], among many others (see for an overview, e.g., [21]), spatially construct regions reflecting on the economic backbones of the continent [22].

The conceptual complexity for constructing regions leads to a struggle to construct them into consistent territorial maps [23]. The geography of the 'space of place' [24], a 'territorially-embedded' thinking of regions, has recently been challenged in a scientific debate by socio-economic arrangements producing 'relational and unbounded' conceptions of regions constituted by the spatiality of flow, juxtaposition, porosity and connectivity [25]. Jessop et al. [26] remark that a region can be imagined and constructed in manifold ways with competing regional imageries and different methods and indicators for region-building-e.g., "from tightly sealed territories to porous nodes in a networked space of flows" (see also [23]). Acknowledging this academic discussion to which degree non-standard regional spaces are replacing territorially bounded regions (e.g., $[27,28])$, we understand the demand for progress in this debate in the line of $[29,30]$ that it is not 'either/or', but rather it is 'both/and' conceptions of territorial and relational perspectives on regions that are required.

Taylor [31] suggests that new data in various disciplines may allow for a more complete geographic understanding of networks looking at both, the place and the flow of space. This paper's contribution is taking advantage from recent developments in Earth observation providing global settlement geoinformation. As Harrison and Growe [23] remark, the academic debate on the new regionalism has raced too far ahead of empirical studies, and scholars promt the need for studies regarding the production of 'new spaces' [32]. We aim to add empirical knowledge on the configuration of Europe's settlement patterns. For this purpose, we elaborate recently generated remote sensing data (i.e., the "Global Urban Footprint" (GUF) [33]) with a European-wide coverage. The GUF data consistently captures not only the large dense urban agglomerations, but also medium dense hinterlands or even small settlement patches in low dense rural areas with a high resolution and precision [34] allowing to tackle regional phenomena. Intrinsically, the focus of this approach using settlement patterns is on territorial thinking (however, not in a political sense of territories, but on territories defined by similar characteristics of the landscape); however, this may also trigger analytical studies about relational processes. The consistency of the Earth observation (EO) data set allows the landscape pattern to be comprehended within its large general geographic context. Moreover, it meets Antrop's [35] demand for detailed inventories of landscape conditions as basis for better decision-making. In comparison to a large amount of literature on spatial structures and patterns focusing on established territorial entities [6], EO data sets are freed from any constraints of territorial jurisdiction. In consequence, this paper's contribution is from a geographical point of view to broaden the search for new territorial phenomena [6] - in a spatially unbiased (possibly traversing regional or national boundaries) way with one consistent data set to identify non-standard territories. Thus, it explores the capabilities and the challenge to define, delimit and designate regions through recent data to construct maps, in our case for the European continent. In doing so, this paper is not intended to contribute to the plurality of possible complementary or contradicting regional logics or a normative assessment of regional phenomena.

From a methodological point of view, this paper contributes to the academic knowledge by introducing a method for node identification (understood as urban center) using settlement densities and size, instead of population data (as, e.g., done by $[14,36])$. These population data may suffer from inconsistencies due to varying acquisition dates or census techniques, among challenges. Furthermore, we extend established methodological approaches on the measurement of spatial settlement contiguity between nodes (based on [37]) and we introduce a method for identifying territories related to these connected nodes; upon this, we introduce a new methodology for categorization of identified networks 
of nodes and respective regions. In consequence, this study is based on one data set as the origin, allowing one methodological logic, and is thus unbiased from possible inconsistencies across time and space, as is often the case when multiple input data across countries are applied. Thereby, we aim to add to the current body of literature making urban remote sensing a relevant data source for urban studies-in our case for a better empirical understanding of node networks and their related settlement patterns in Europe.

\section{Conceptual Background}

There is a consensus that the term 'region' refers to space. However, the construction of space itself can rely on different indicators and logics, and intrinsically features several imageries or meanings: territorial space; political space; space of social interaction; economic space; functional space; institutional space [2]. The scientific debate regarding the mentioned new regionalism demands multidimensional perspectives; the indicators, which define, delimit or construct regions, however, stay conceptually vague [4]. Rather it is a plural of regional logics [38] that allow the definition of virtual imagined spaces on the one hand, as well as geographic delimitations of territorial regions on the other hand. While we understand regionalism as Harrison and Growe [23] postulate, as both, relational and territorial as complementary alternatives, our point of origin - the recently developed binary classification mapping settlement vs. non-settlement areas-defines territorial space as our conceptual foundation. Our construction of regions is thus related to similar characteristics of settlement patterns, an indicator suggested among others, e.g., by [39] to construct geographically linked mega-regions.

In consequence, this study does not allow for the construction of multidimensional, possibly complementary spaces; a de facto 'both/and' study where relational and territorial spaces are alternatives is not intended. However, when we consider the postulated priviledging of cities in relational conceptions of regions constituted through the spatiality of flow, juxtaposition, porosity and connectivity $[23,25]$, cities are the pivotal nodes of globalizaton (e.g., of an (inter)national trade network [35]). These pivotal nodes are anchor points constructing virtual, imagined regions. Our consistent European wide geoinformation on settlement patterns does not allow to (re-)construct those non-spatial imagined regions; however, it allows us to identify cities (as central, pivotal nodes) as spaces of relevance by their physical characteristics. In the line of the argument of authors like Glaeser [40], Florida et al. [7], Harrison and Growe [23] or Scott [13] cities and related regions are focal points for economic turnovers, knowledge creation, learning and innovation fostering postnational identities and social cohesion. The permanency of human settlements makes them a testimony of location-based current and/or historical success. Furthermore, Krehl et al. [41] or Taubenböck et al. [42], e.g., show that concentration of built-up masses physically reflects to the concentration of economic functions. In consequence, the growth (size) and convergence (density) of settlement patterns is the predominantly visible result of economic development. Or as Antrop [35] argue, urbanization is a complex of functional changes, followed by morphological and structural ones. In times where settlements are expanding due to population growth or migration into cities [43], new nodes within networks may develop and their physical convergence and contiguity can function as one (of many other possible) proxy for urbanization and the related crucial functions connotated to metropolitan areas of relevance. These conceptual considerations support territorial thinking about relational processes [23,30]. However, it is not our aim to privilege this single dimension, but to present this one dimension as a possible feature to describe current (and historical) socio-spatial landscapes allowing us to relate other dimensions to it in future studies.

Beyond this, the nodes may be the origin for virtual, imagined spaces; but, they also comprise location-based interrelated elements: the city, which posseses some specified sets of functions or economic activity, and the region, a surrounding territory that is exclusive to that city $[13,44]$. Rapid urbanization sees functional economies of most large cities extend far beyond their traditional boundaries to capture physically separate yet functionally networked cities and towns in the surrounding hinterland [23]. With it, we take into account that regional economic and political 
interests continue to be expressed in a territorial fashion [45]. The thinning of the settlements into the hinterland is a physical representation of these territorial linkages. However, there is no point in the continuum from large urban agglomerations to small clusters or scattered dwellings where urbanity disappears and rurality begins [46]. Thus, the division between urban and rural is necessarily fuzzy [35]. Furthermore, urbanization processes may interlink two or more previously independent cities potentially complementary in function, which achieve significant scope economies by cooperation [47]. This may materialize via many types of networks, such as a joint public transportation network, highways and high-speed rail systems, communication infrastructure, people commuting across the cities or the proxy we apply in this study, the convergence of settlements. We are aware that significant linkages between nodes for one indicator are not necessarily reflected in others. This means, regions are not fixed, but fuzzy territorial entities (soft spaces), boundaries are malleable based on the criteria used or the thresholds defined (e.g., [48,49]).

Based on these considerations, our proposed methods (Section 3) using settlement patterns as proxy relate to a hierarchical, multi-scale construction of space by nodes, connectivity between nodes and related regions. The identification of cities as central nodes (by settlement size and density), and the evaluation of connectivity between identifed nodes (by settlement contiguity and density) creates one spatial level which is not territorially fixed, but somehow bounded. The delimitation of regions related to the nodes (by density) is another spatial level of territorially fixed, bounded spaces. With the one, consistent EO-based data set, our approach allows one logic without pre-defined borders or spatial entities for identifying non-standard contiguous city networks and contiguous regions.

\section{Data and Methods}

For the identification of regional phenomena related to similar charactistics of settlement patterns across Europe, we present in the following the data sets used, the developed chronologic workflow and the methodological steps. We illustrate these steps as a schematic overview (Figure 1) and explain accordingly the respective ideas, concepts, data and methods below. At a glance, we start with the GUF as one data set of origin (Figure 1a); from it we derive settlement density (Figure 1b) and identify, based on settlement characteristics, the nodes of relevance (Figure 1d); for the latter, we use auxiliary geodata to calibrate meaningful thresholds (Figure 1c). We determine relevant node connections (Figure 1e) and calculate least-cost paths between nodes (Figure 1f) for evaluation of highest possible settlement contiguity between them (Figure 1g). Subsequently, we map territorial regions around the identified nodes (Figure 1h) and categorize these regions by physical characteristics (Figure 1i). Finally, we check the plausibility of our results by a set of auxiliary data, e.g., an urban-rural typology or the population distribution (Figure 1j). 


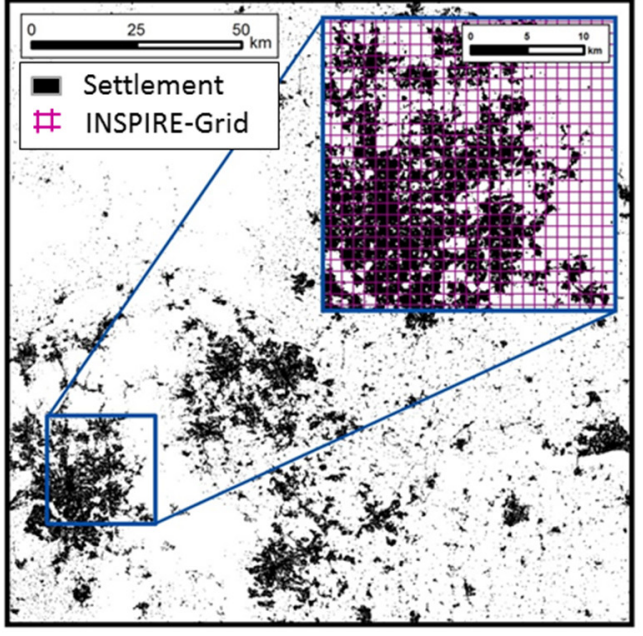

a) Global urban footprint

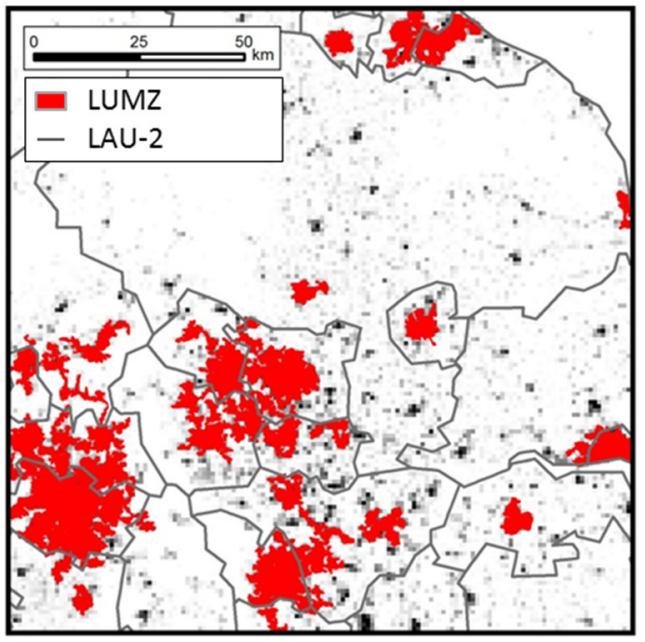

c) Auxilliary geodata

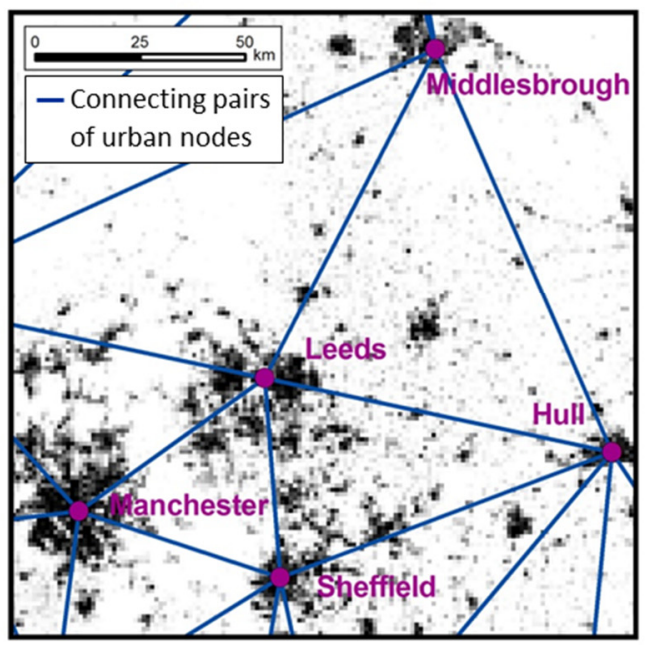

e) Triangulation

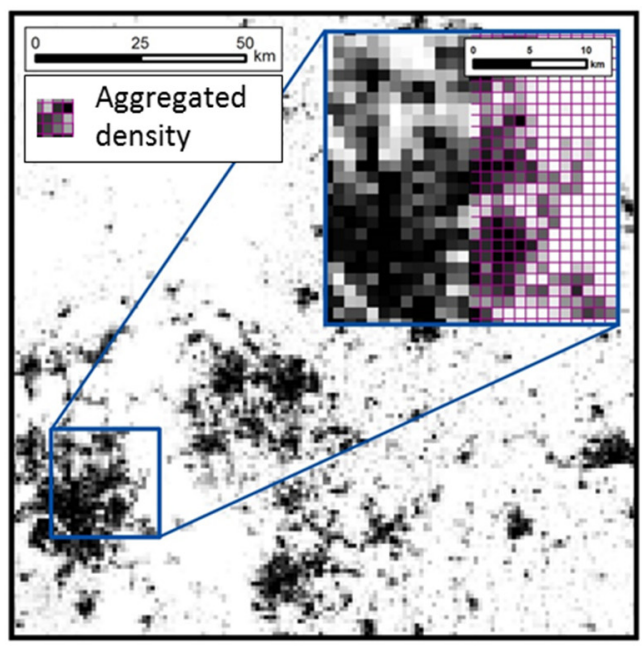

b) Derivation of settlement density (INSPIRE-Grid)

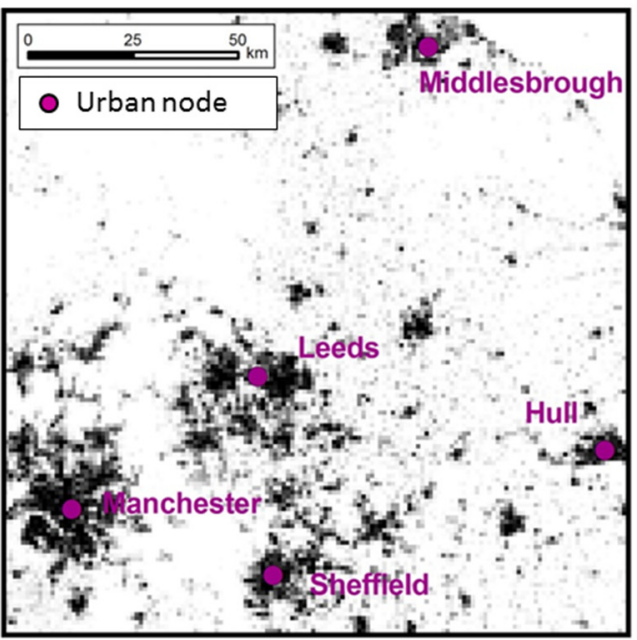

d) Identification of urban nodes

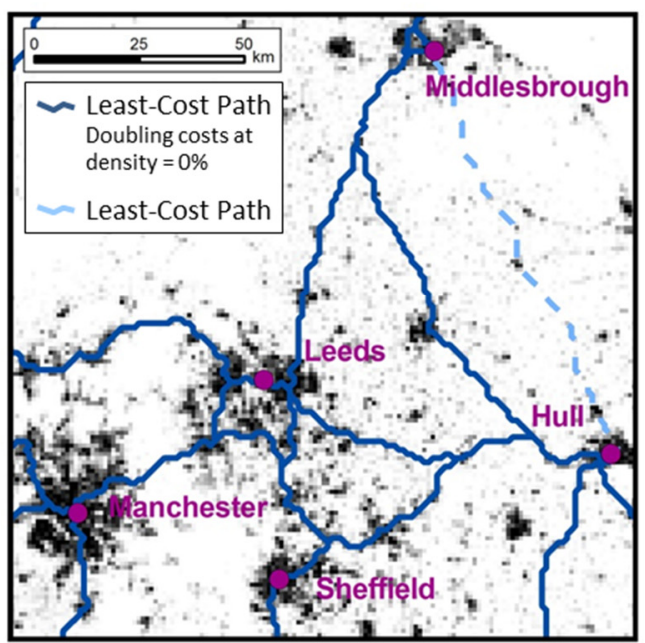

f) Calculation of conjugation lines (least-costpaths)

Figure 1. Cont. 


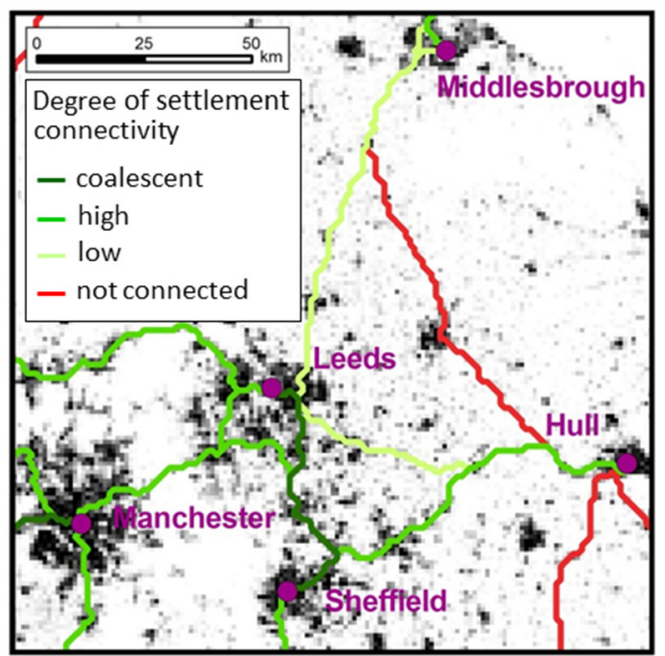

g) Classification of conjugation lines

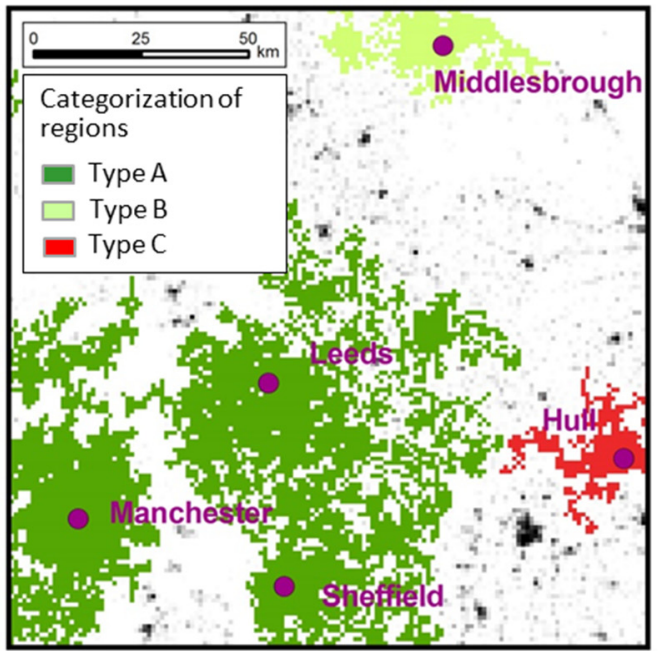

i) Categorization of city network regions

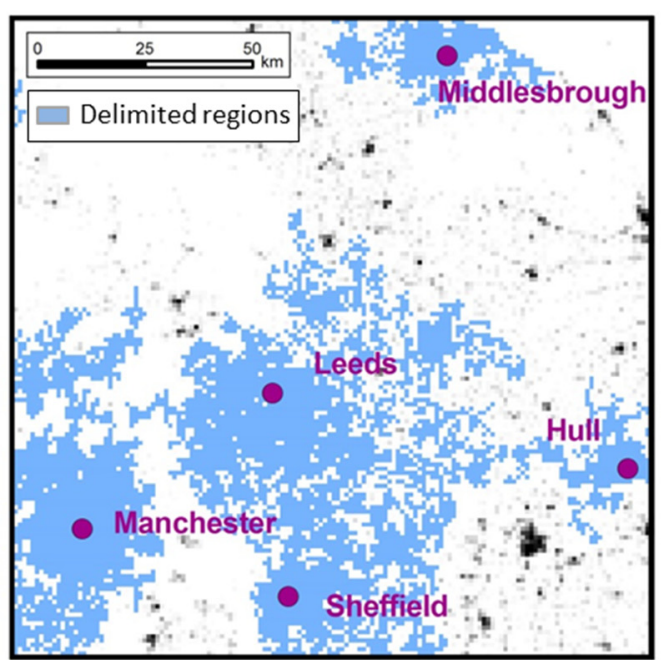

h) Delimitation of city network regions via region growing

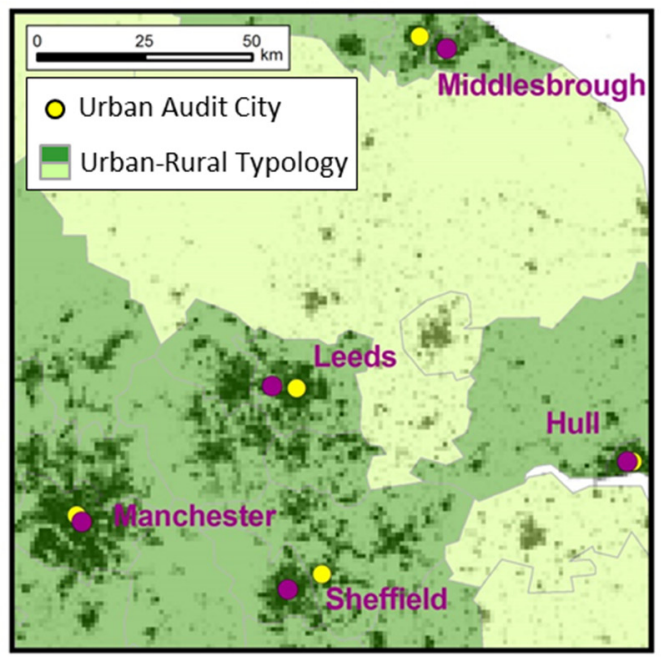

j) Plausibility check using auxilliary data

Figure 1. Schematic overview of the workflow with the used input and auxiliary data sets, the applied methodological steps, the geographic results and the assessment of plausibility. (a) Global urban footprint; (b) Derivation of settlement density (INSPIRE-Grid); (c) Auxilliary geodate; (d) Indentification of urban nodes; (e) Triangulation; (f) Calculation of conjugation lines (least-cose paths); (g) Classification of conjugtion lines; (h) Delimitation of city network regions via region growing; (i) Categorization of city network regions; (j) Plausibility check using auxilliary data.

(a) Global Urban Footprint (GUF): With the GUF [33] (as well as with other current initiatives such as the Global Human Settlement Layer (GHSL) [50]) mapping of global settlements and their patterns entered a new era with an unprecendented spatial resolution of $12 \mathrm{~m}$. Using TerraSAR-X/TanDEM-X data, the classification algorithm detects high reflectance values (scattering centers mainly caused by vertical man-made structures such as buildings) in areas of comparatively high texture measures. The mapping result must be understood as an abstract delineation of settlement areas [51].

The most important advantage over previous large area settlement classifications (e.g., global classifications based on MODIS [52], MERIS (e.g., [53]) or night-time lights [54] or continental data sets such as CORINE land cover or soil-sealing [55]) is the improved capability of preserving the small-scale complexity of settlement patterns beyond the urban core in rural environments. 
As shown by Klotz et al. [34] the high spatial resolution of TerraSAR-X/TanDEM-X data allows detecting scattered small settlements; these low density settlement regions are significantly underrepresented in previous data sets due to larger minimum mapping units. In consequence, this improved capability of the GUF data espcially improves the accuracy of the settlement density calculation in peri-urban or low dense rural environments, even when aggregated onto the $1 \mathrm{~km}$ grid (see below). This is a decisive improvement, when analyzing the contiguity of the built environment between nodes along with its area-wide coverage in consistent manner.

(b) Derivation of settlement density: Density refers to the accumulated settlement area within a respective reference area. The size and location of the reference areas is crucial in the context of density and subject to the modifiable areal unit problem (MAUP) (e.g., [56]). As there is no 'one-size-fits-all' geographical unit and for reason of consistency, we calculate settlement density with respect to the spatial unit of $1 \times 1 \mathrm{~km}$ using the INSPIRE (Infrastructure for the Spatial Information in the European Community) grid, which is a standardized raster across Europe. The resulting gridded settlement density serves as one, consistent input geodata set to identify nodes across Europe, to evaluate connectivity between nodes and to define territorial regions related to the nodes.

(c) Auxillary data: Along the various components of the developed methodology, we make use of auxillary data sets for reasonable threshold development or plausibilization of results. For the identification of urban nodes (cf. Figure 1d and (d) below), we use the Larger Urban Morphologogical Zones (LUMZ) [57] to determine the minimum settlement density necessary to qualify for a node; the LUMZ describe the tissue and function of a zone integrating thematic urban core classes; it is based on core classes of the Corine Land Cover data set such as 'continuous urban fabric' or 'industrial and commercial units', among others [58]. Compared to the approach in our study using solely settlement density dervied from the GUF data, the LUMZ result from the combination of multiple information on urban functions and built-up. For the derivation of minimum sizes of nodes (cf. Figure 1d and (d) below), we utilize the accepted standard of Level-2 Local Administrative Units (LAU-2). These entities entail municipalities or the like as a common statistical unit across the $28 \mathrm{EU}$ member states [59]. For threshold development evaluating if nodes are connected or not (cf. Figure $1 \mathrm{~g}$ and $(\mathrm{g})$ below), we use the urban-rural typology at NUTS-3 regional level featuring the classes predominantly urban, intermediate and predominantly rural [59]. For plausibilization (cf. Figure $1 \mathrm{j}$ and ( $\mathrm{j}$ ) below), we draw on the population grid at the $1 \mathrm{~km}$ INSPIRE grid [58]. As the population grid does not include non EU member states, the plausibilization is not done for the entire spatial extent of Europe. Beyond that we use Urban Audit Cities (UAC) for plausibilization of our results by comparing them to our identified nodes (cf. Figure $1 \mathrm{j}$ and (j) below). The UAC are classified based on certain criteria such as 'population must exceed 50.000 inhabitants', among others [60].

(d) Identification of urban nodes: What defines an urban node? In other studies relevant urban nodes are often defined by thresholds applied to data on population, concentration of acitivies, or economic turnovers, among other parameters of the respective city (e.g., $[14,36,61,62])$. Taking advantage of the GUF classification, we approach this issue uncoupled from, e.g., population data as these data often have consistentcy issues at continental scale (e.g., the population grid from Eurostat [63] (cf. (c) above) is not available in consistent manner outside EU member states). With a solely physical approach using one conistent data set, we aim at identifying relevant urban nodes by the pattern of the settlement. We assume a node of relevance features a comparatively large area of high settlement density.

With respect to those two variables-high settlement density and comparatively large area of high settlement density - we aim at finding meaningful thresholds for identifying urban nodes. Of course, any threshold defining an urban node of relevance is at risk to be subjective. However, for a reasonable approach we use the introduced auxilliary data set, the LUMZ, to develop a density threshold. We calculate the mean settlement density for all LUMZ derived from the GUF 
data across Europe and use the resulting mean density value (61.3\%). We apply this threshold to define pixels indicating a node by settlement density. However, as a very large number of individual pixels as well as small adjacent groups of pixels fulfill this requirement across Europe, we use the second criterion to identify only nodes with a significant size of area of continuous high settlement density. What defines a significant size is, of course, also malleable; for our straight-forward approach, we rely for the development of a reasonable threshold on a previous study, in which the Ruhr-Randstaad mega-region was analyzed with respect to the built environment [14]. We take from all nodes in their study (identified by population) the smallest administrative size (as provided in the LAU-2 regions) as threshold defining the mimimum size for a node of relevance $\left(30 \mathrm{~km}^{2}\right)$. For every area detected across Europe fulfilling both criteria—high settlement density and comparatively large area of high settlement density-we locate the urban node as geometric centroid within the respective area.

(e) Triangulation: After having located all urban nodes by the conditions introduced above, we aim to assess spatial connectivity between these cardinal points. We use a triangulation technique for creating a mesh of contiguous, non-overlapping triangles from this dataset of nodes. With it, we identify which conjugation lines between nodes need to be analyzed regarding settlement contiguity.

(f) Calculation of conjugation lines by a least-cost path method: We aim at evaluating the connectivity of settlement patterns between two identified urban nodes based on the density of the settlement pattern in between. To find the highest possible density in combination with the shortest possible distance between nodes, we apply a least-cost path method (as introduced by [37]). With the settlement density as cost surface layer, the algorithm calculates the undirected least accumulated travel cost (or shortest weighted distance) from the starting node to the destination node. For the special case that the density of the cost surface layer is $0 \%$, we double the costs for this specific grid. We do so as we intend to find contiguity of the settlements between nodes. In Figure 1c the example between Middlesborough and Hull shows the effect of this measure. With it we achieve least-cost pathes favouring settlement areas over possibly shorter distances with non-settlement areas. The algorithm adds all costs per pixel of the cost surface layer raster for every individual path possible until a particular path reaches the destination node. The path with the least costs accumulated between two hubs is then finally selected.

(g) Classification of the conjugation lines: We assume spatial connectivity between two nodes is given if settlement patterns are continuous without significant interruptions or decrease to rural environments (low settlement density). To account for these assumptions, we classify the magnitude of spatial connectivity $(\mathrm{MoC})$ along the conjugation lines using two parameters: average settlement density and percentage of pixels featuring a settlement density higher than $10 \%$. The average settlement density ensures that the demanded high share of settlement between nodes is measured; the percentage of low density areas ensures that continunity by a low share of spatial disconnections along the path is measured.

We evaluate higher connectivity with a rising average settlement density. Simultaneously a higher $\mathrm{MoC}$ relates to a higher percentage of pixels with settlement densities higher than $10 \%$. To take both variables into account, we combine them by multiplication. Thus, the magnitude of spatial connectivity $(\mathrm{MoC})$ between two nodes is calculated as follows:

$$
\mathrm{MoC}=\frac{\sum_{k=1}^{n} \mathrm{~d}(\mathrm{k})}{n} \times\left(\frac{100}{n} \times p\right) \quad 0 \leq \mathrm{MoC} \leq 100
$$

where $n$ is the number of all pixels along a particular path, $d$ is the value of the settlement density of a particular pixel, and $p$ is the amount of pixels higher than $10 \%$ settlement density along the particular path (based on the methodology introduced by [37]). 
The resulting $M o C$ index has a range between 0 and 100. Nevertheless, the MoC index does not define whether conjugation lines are spatially connected or disconnected. Being conscious of the fact that there may no obvious, natural or objective threshold exist that definies whether two nodes are spatially connected or not, we again use an auxilliary data set, the urban-rural typology, for a reasonable threshold development. We assume that predominantly urban zones may function as a good indicator whether nodes are connected or not. We calculate all MoC values for all conjugation lines with a starting and a destination node located in one or in coalescent predominantly urban zones. From all $\mathrm{MoC}$ values derived we use the minimum MoC as threshold to define whether two nodes are classified spatially connected or not.

Subsequently, as we find a high variability of MoC values classified as connected across Europe, we group them into three classes. To do so, we apply the Jenks-Caspall natural breaks classification method [64]. The data clustering method allows identifying the best arrangement of values into different classes (we define three classes for all conjugation lines classified as connected-coalesced, high spatial connectivity and low spatial connectivity). We additionally classify all conjugation lines assigned 'not connected' into two classes, 'very low' and 'no' connectivity using the natural break algorithm. This lets us assume which conjugation lines may hold potential to become 'connected'.

Overall, the result is a classification of all conjugation lines into two major classes: disconnected (with specifications into very low and no connectivity) and connected (with specifications into low connectivity, high connectivity and coalesced). The connected conjugation lines may span unterritorial regions by these bounded nodes.

(h) Delimitation of city regions via region-growing: Let us assume two pairs of nodes are spatially eqally connected via a classified conjugation line; one along a narrow strip of high settlement density along a development axis (e.g., a highway) and, in contrast, one additionally surrounded by high settlement densities in the hinterland. Both conjugation lines of both pairs of nodes indicate a connected network by settlement patterns; however, the region to be considered part of the network may vary significantly due to their different shapes of high dense settlement patterns.

Since no unambiguous classification criteria for a distinction between the node and the surrounding hinterland of lower settlement density exists, we delimit city regions via a region-growing approach. To do so, we consider all identified nodes featuring at least one conjugation line classified as connected as seed pixels. We allow a region-growing around the seed pixels if neighoring pixels feature a mean settlement density not lower than $2.5 \%$ settlement density, as this density value is above the European mean $(2,05 \%)$ and these areas cover only $11.14 \%$ of the whole of Europe. The region-growing is conducted until a loop is not changing the resulting pattern. If regions originating from different nodes merge by the region-growing we consider them as one region.

(i) Categorization of regions: From the region-growing approach we derive spatially coalesced patches defining territorial entities related to the identified nodes. As we find a high variability of regions across Europe (in extent, in number of nodes, in connectivity, etc.), we categorize the resulting regions by the following variables: the number of nodes within the region; a higher number of nodes indicates a higher relevance of the region. The average path length of connected cities within the region; a smaller average path lenghts indicates a more clustered arrangement of nodes. In consequence, we assume the degree of connectivity within the region is higher. A class index, quantifying the percentage share of low connectivity, high connectivity and coalsced types of all conjugation lines within one region. We assume the higher the shares of stronger connectivity, the higher the degree of settlement continuity is within the region. The spatial dimension of the extent of the region; with larger extents indicating higher relevance of a region.

For the categorization we take all four variables into account and combine them by multiplication. From the resulting index values—a higher value indicating a region with more nodes, more 
clustered arrangement, higher connectivity and larger extent-we classify five groups (Category $A-E)$ using the natural breaks algorithm. Furthermore, we classify a Category $F$ for all remaining nodes not associated to a region.

(j) Plausibilization of classification results: It is obvious that there is not 'one truth' for an urban node of relevance, a specific region, or the spatial delimitation of conceptual approaches such as a mega-region. Beyond this, reference data are either inexistent or rely on other data, concepts and methods. An assessment of correctness in its original sense is thus not meaningful. What is considered a node or a region is, although mathematically reasonable, subjective to the selected indicator 'settlement pattern' and the related threshold selections and, it is also relative at the same time. We disregard a sensitivity analysis here, as the systematic evaluation of the manifold influences onto the results from the scale of measurement (here $1 \times 1 \mathrm{~km}$ ), the thresholds for defining nodes of relevance (by density and size), the thresholds evaluating connectivity or defining the region-growing is beyond the scope of one paper. Instead we refer to a recent paper by Taubenböck et al. [65] performing sensitivity analysis for settlement density variables, and argue that the main point in our study is the consistency of the application. However, to provide an assessment of the results, we check the plausibility of our physical approach to identify nodes ((1) and (2) in the following) and regions (3) in relation to other related data sets as well as to constructed regional spaces in other studies (4).

(1) We relate all identified nodes to the urban-rural typology at NUTS-3 regional level. As our physical analysis relies on high settlement density for the identification of nodes, we await identified nodes to be located in the predominantly urban class. (2) We relate identified nodes to Urban Audit Cities (UAC). We assess plausibility of our physical analysis by checking the percentage of identified nodes located within a certain distance to an UAC. We assume our approach is feasible if the data sets do not differ significantly. (3) We check the plausibility of the derived regions by checking the following assumption. As the detected regions are areas of physical concentration (high settlement densities), we expect the population in the mapped areas to have a higher share than the settlement share. (4) We qualitatively compare constructed territorial regions from other studies (based on varying data, concepts and methods) with our results.

\section{Results}

\subsection{Mapping of Nodes, Connectivities of Nodes and Regions}

Our approach using settlement pattern as an indicator allows a multi-scale perspective on focal urban areas across Europe: (1) the localization and distribution of nodes of relevance; (2) the classification of spatial connectivites between these nodes; (3) the unterritorial, but somehow bounded space spanned by those nodes; (4) the spatial mapping of territorial regions. Figures 2-4 integrate the different results and illustrate soft as well as territorial spaces. Although the analysis has been conducted for the whole of Europe, Figures 2 and 4 do, for reason of illustration, not present the entire continent (e.g., parts of Scandinavia and related conjugation lines are left out of the visualization). However, this visualization allows for focusing on the identified focal areas of Europe in sufficient size and detail with no conjugation line classified as connected been left out.

\subsubsection{The Nodes and Spatial Connectivity between Nodes (Constructing Non-Territorial Regions)}

In general, our applied methodology using two spatial variables-high settlement density and significant coalescent size of high settlement density-results in 240 identified nodes across the European continent, from which $66.3 \%$ are, due to their density of conjunctive settlement patterns, identified as being part of a physical network forming regions.

These connected nodes span soft spaces across Europe, corresponding to constructed regional spatial entities suggested in other studies, such as the 'Blue', 'Yellow' or 'Sunbelt Banana', the 'red 
octopus or the 'blue star'. Our approach identifiying the maximum spatial connectivity between nodes enables the reconstruction of those conceptions in higher spatial detail; beyond, we find deviations from those constructed spaces as well.

The dominating core of spatially connected nodes is identified in central and western Europe (Figure 2). Neglecting the topographically separating element of the Atlantic Ocean between Great Britain and the European main land, the connected soft space is transnationally strechting from central England to northern Italy via The Netherlands, Belgium, Luxembourg, France, Germany and Switzerland. This settlement pattern basically reflects the Blue Banana ([17]). This conception has been titled the backbone of European economic development originating along century-old trade routes and from an industrial past, sometimes terminologically called an urban corridor (or also called city belt, central European urban region, central megalopolis) [22,66]. However, comparing the identified nodes of this network spanning an unterritorial soft space with the original spatial delimitation from RECLUS [17] (although back then done on a coarser spatial level of territorial delimitation) allows us to conclude that the Blue Banana has expanded beyond the indicated former shape. Paris and its surrounding city regions (back then evaluated as not connected to the Blue Banana) are now classified as connected to the large network; in England the network today expands further to the north to Newcastle; the network also expands to central/northern Germany to Hamburg and Hannover, and to the southeast towards Munich along new development axes. The soft space also expands its shape towards Lyon and Marseilles in France and it extends the previous shape via the entire northern part of Italy even to Ljubijana (Slovenia), and to the south towards Florence. This non-territorial but spatially streched area is still characterized by the Blue Banana as backbone, but today shows many detours from its main body indicating newly developing axes. It's dominating character in quantitative manners is shown as $51.7 \%$ (with $36.7 \%$ on the European main land and $15 \%$ in the UK) of all identified nodes across Europe are spatially connected to this network.

As already mentioned, the Yellow Banana-from Paris to Warzaw-is developing in bricks which are not yet measured as fully connected by nodes (Figure 2), but confirming the expected rise of this development direction [22]. Also for the Sunbelt Banana-from Milan to Valencia [22] - these connected bricks are detected; we even idenfity an expansion beyond Valencia to Alicante and Murcia, and along entire northern Italy; however, Montpellier and Barcelona are due to the topographic barrier of the Pyrenees not yet classified as connected, interrupting this development axis. Overall, these spatial entites of connected nodes are spatially very well reconstructing, but also extending the European 'blue star' map introduced by IAURIF [20] or the 'red octopus' [19];).

All other detected soft spaces across Europe, most notably the strech from Lisbon to Vigo, are basically constructed by only 2 or 3 nodes and in comparison to the mentioned backbones of Europe small entities. In general, the spatial distribution of nodes shows larger distances between nodes further to Europe's east. The method also visualizes how, e.g., nodes of relevance such as the national captials Madrid, Stockholm or Bucharest are spatially isolated to other nodes. Compare the details on spatial expansion, nodes and connectivites in Tables 1 and 2. 


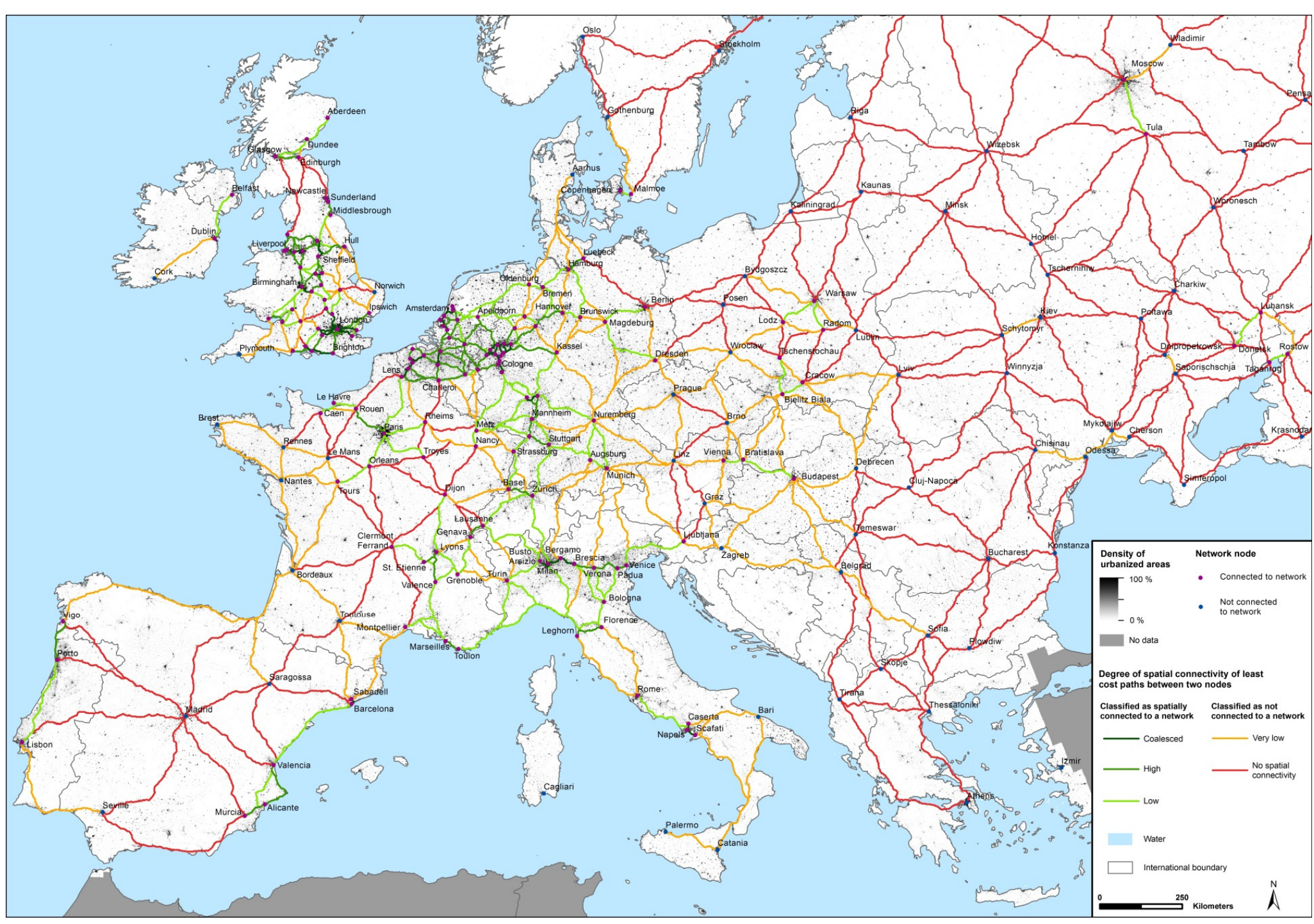

Figure 2. The identified urban nodes and the classification of conjugation lines connecting these nodes across Europe. 


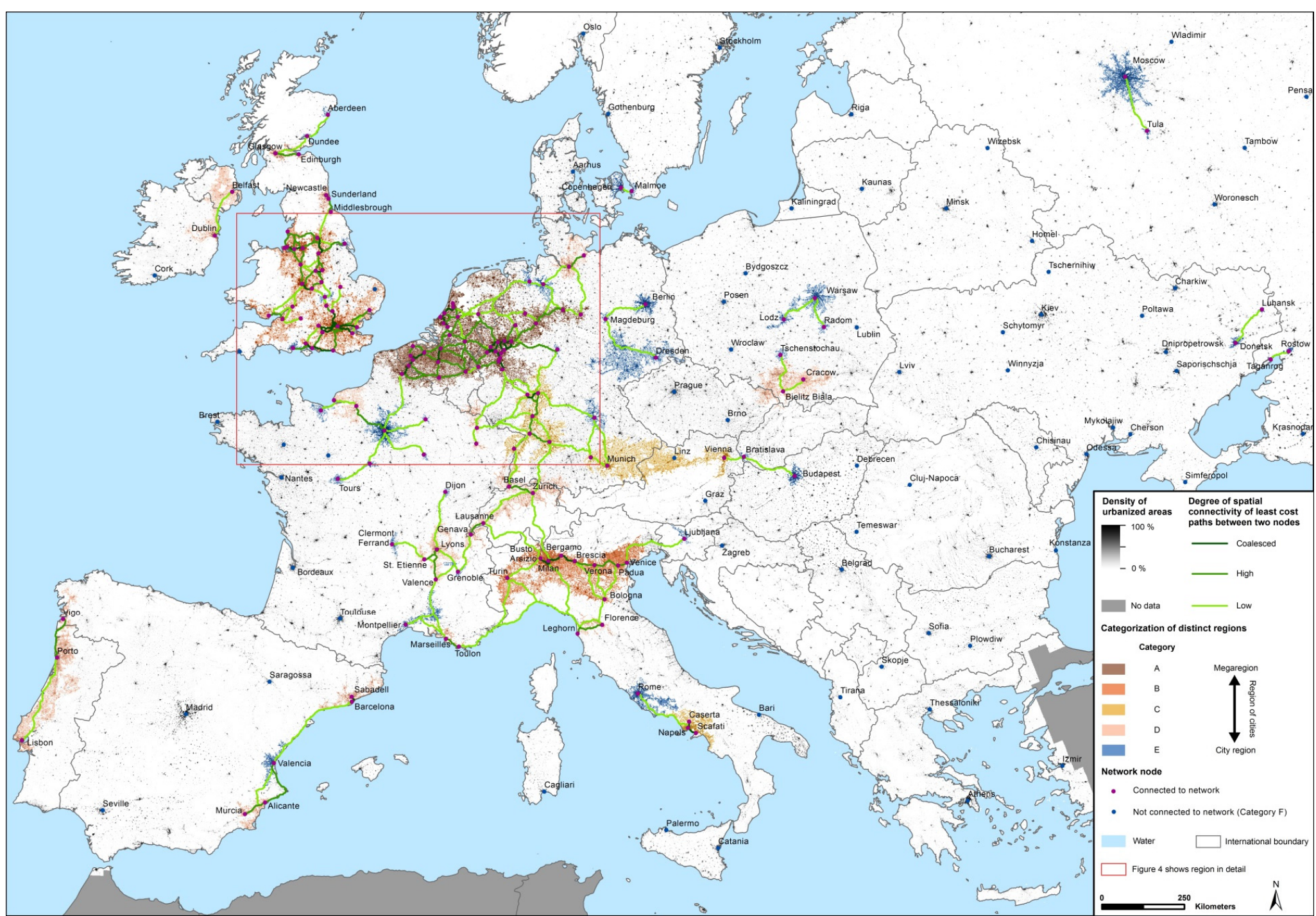

Figure 3. The identified urban nodes, the conjugation lines classified as connected and the categorized delimited regions. 


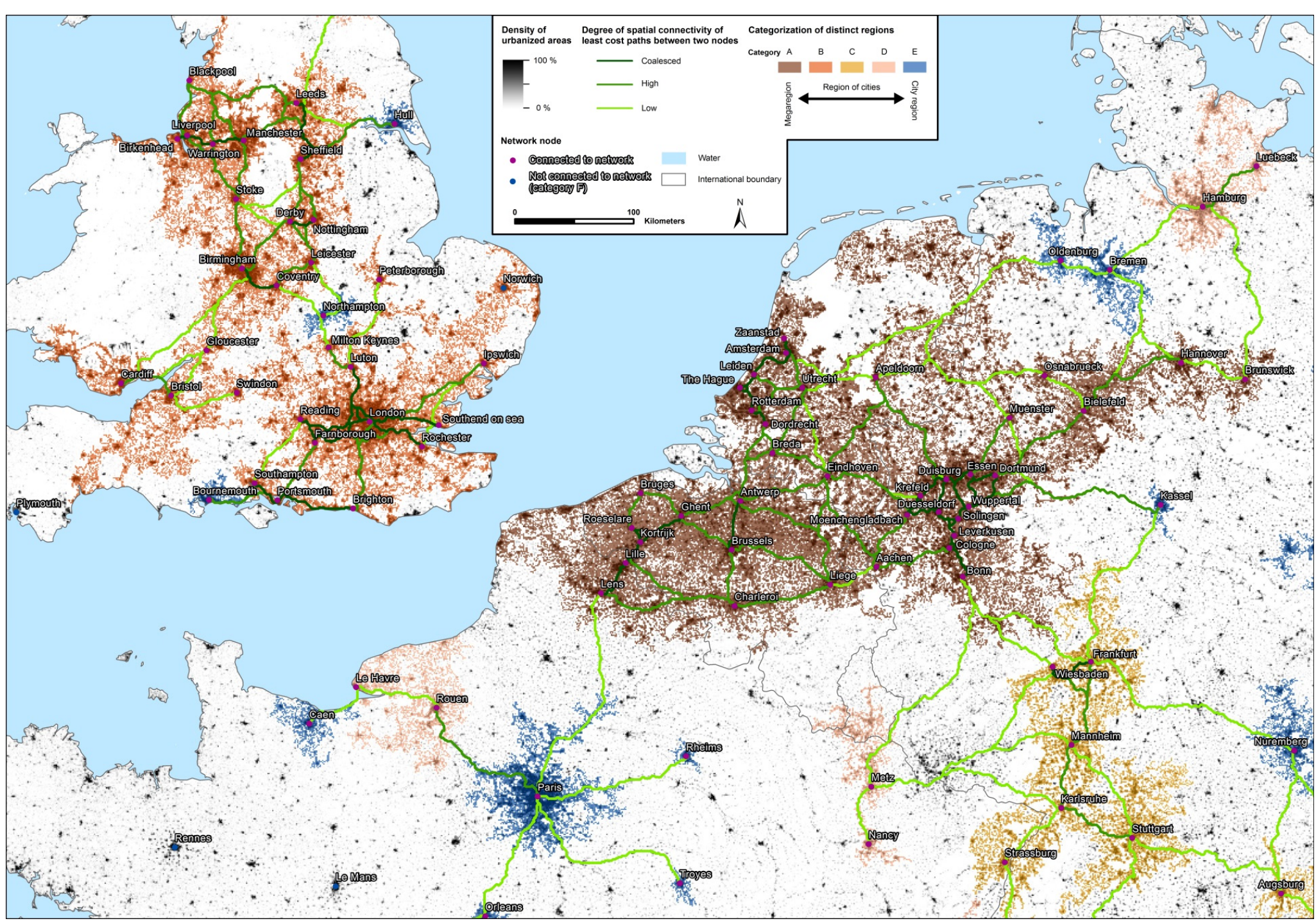

Figure 4. Identified urban nodes, conjugation lines classified as connected and the categorized delimited regions from the detail in Figure 3. 
Table 1. Detailed quantitative characterization and categorization of the identified territorial regions and their respective nodes (Category A-D).

\begin{tabular}{|c|c|c|c|c|c|c|c|c|}
\hline \multirow[b]{2}{*}{ Category } & \multirow[b]{2}{*}{ Classified Nodes (Cities per Region) } & \multirow[b]{2}{*}{ Spatial Expansion } & \multicolumn{4}{|c|}{ Physical Indicators } & \multirow[b]{2}{*}{ Index } & \multirow[b]{2}{*}{$\begin{array}{l}\text { Absolute } \\
\text { Population }\end{array}$} \\
\hline & & & No. (Cities) & $\begin{array}{l}\text { Areal Expansion } \\
\left(\mathrm{km}^{2}\right)\end{array}$ & $\begin{array}{c}\text { Mean Length } \\
\text { Conjugation } \\
\text { Lines }(\mathrm{km})\end{array}$ & $\begin{array}{l}\text { Connectivity } \\
\text { Index }\end{array}$ & & \\
\hline A & $\begin{array}{l}\text { Lens, Lille, Kortrijk, Roeselare, Bruegge, Gent, } \\
\text { Brussels, Charleroi, Antwerpen, Luettich, } \\
\text { Aachen, Moenchengladbach, Duesseldorf, } \\
\text { Solingen, Wuppertal, Leverkusen, Koeln, } \\
\text { Bonn, Duisburg, Essen, Dortmund, Krefeld, } \\
\text { Muenster, Bielefeld, Osnabrück, Hannover, } \\
\text { Braunschweig, Eindhoven, Breda, Dordrecht, } \\
\text { Rotterdam, Utrecht, Den Haag, Leiden, } \\
\text { Amsterdam, Zaanstad, Apeldoorn }\end{array}$ & $\begin{array}{l}\text { Transnational } \\
\text { (France, Belgium, } \\
\text { The Netherlands, } \\
\text { Luxembuorg, } \\
\text { Germany) }\end{array}$ & 37 & 65,253 & 69 & 1.32 & 28.04 & $51,048,827$ \\
\hline \multirow{3}{*}{$\mathrm{B}$} & $\begin{array}{c}\text { Swindon, Bristol, Cardiff, Gloucester, } \\
\text { Birmingham, Coventry, Leicster, Nottingham, } \\
\text { Derby, Stoke, Warrington, Liverpool, } \\
\text { Birkenhead, Manchester, Sheffield, } \\
\text { Leeds, Blackpool }\end{array}$ & $\begin{array}{l}\text { National (United } \\
\text { Kindom) }\end{array}$ & 17 & 22,080 & 76 & 1.24 & 3.720 & $23,897,718$ \\
\hline & $\begin{array}{l}\text { Turin, Busto Arsizio, Mailand, Bergamo, } \\
\text { Brescia, Verona, Padua, Venice, Bologna }\end{array}$ & National (Italy) & 9 & 31,388 & 100 & 1.22 & 2.105 & $20,809,095$ \\
\hline & $\begin{array}{l}\text { London, Southend on the sea, Rochester, } \\
\text { Ipswhich, Norwhich, Brighton, Farnborough, } \\
\text { Reading, Southampton, Portsmouth, } \\
\text { Peterberough, Luton, Milton Keys }\end{array}$ & $\begin{array}{l}\text { National (United } \\
\text { Kindom) }\end{array}$ & 13 & 16,473 & 83 & 1.31 & 1.891 & $21,020,358$ \\
\hline \multirow{3}{*}{$\mathrm{C}$} & $\begin{array}{c}\text { Frankfurt, Wiesbaden, Mannheim, Karlsruhe, } \\
\text { Stuttgart, Straßburg }\end{array}$ & $\begin{array}{c}\text { Transnational } \\
\text { (Germany, France) }\end{array}$ & 6 & 13,656 & 88 & 1.19 & 0.673 & $13,303,103$ \\
\hline & $\begin{array}{l}\text { Augsburg, Munich, Vienna, Linz (the city } \\
\text { Linz is not connected via the conjugation line, } \\
\text { but part of a region) }\end{array}$ & $\begin{array}{c}\text { Transnational } \\
\text { (Germany, Austria) }\end{array}$ & $3(4)$ & 17,794 & 64 & 1.0 & 0.509 & $9,399,535$ \\
\hline & Neapel, Caserta, Scafati & National (Italy) & 3 & 4462 & 37 & 1.5 & 0.333 & $5,283,131$ \\
\hline
\end{tabular}


Table 1. Cont.

\begin{tabular}{|c|c|c|c|c|c|c|c|c|}
\hline \multirow[b]{2}{*}{ Category } & \multirow[b]{2}{*}{ Classified Nodes (Cities per Region) } & \multirow[b]{2}{*}{ Spatial Expansion } & \multicolumn{4}{|c|}{ Physical Indicators } & \multirow[b]{2}{*}{ Index } & \multirow[b]{2}{*}{$\begin{array}{c}\text { Absolute } \\
\text { Population }\end{array}$} \\
\hline & & & No. (Cities) & $\begin{array}{l}\text { Areal Expansion } \\
\left(\mathbf{k m}^{2}\right)\end{array}$ & $\begin{array}{c}\text { Mean Length } \\
\text { Conjugation } \\
\text { Lines (km) }\end{array}$ & $\begin{array}{l}\text { Connectivity } \\
\text { Index }\end{array}$ & & \\
\hline \multirow{13}{*}{$\mathrm{D}$} & Basel-Zurich & $\begin{array}{c}\text { Transnational } \\
\text { (Switzerland, } \\
\text { France, Germany) }\end{array}$ & 2 & 9457 & 88 & 1.25 & 0.165 & $7,178,119$ \\
\hline & Cracow-Bielitz Biala & $\begin{array}{l}\text { Transnational } \\
\text { (Poland, Czech } \\
\text { Republic) }\end{array}$ & 2 & 9959 & 79 & 1.00 & 0.161 & $7,503,593$ \\
\hline & Vigo-Porto-Lissabon & $\begin{array}{l}\text { Transnational } \\
\text { (Potugal-Spain) }\end{array}$ & 3 & 15,314 & 232 & 1.13 & 0.136 & $8,941,183$ \\
\hline & Geneva-Lausanne & $\begin{array}{l}\text { Transnational } \\
\text { (Switzerland, } \\
\text { France) }\end{array}$ & 2 & 2392 & 60 & 1.25 & 0.061 & $1,853,763$ \\
\hline & Dublin-Belfast & $\begin{array}{l}\text { Transnational } \\
\text { (Ireland, North } \\
\text { Ireland) }\end{array}$ & 2 & 7555 & 167 & 1.25 & 0.057 & $3,237,883$ \\
\hline & Nancy-Metz & $\begin{array}{l}\text { Transnational } \\
\text { (France, } \\
\text { Luxembuourg, } \\
\text { Belgium) }\end{array}$ & 2 & 2383 & 59 & 1.00 & 0.050 & $1,229,523$ \\
\hline & Barcelona-Sabadell & National (Spain) & 2 & 3390 & 22 & 1.50 & 0.281 & $6,290,076$ \\
\hline & Lyon-Saint Etienne-Valence & National (France) & 3 & 5479 & 87 & 1.17 & 0.132 & $3,422,285$ \\
\hline & Newcastle-Sunderland-Midellsborough & National (UK) & 3 & 1857 & 42 & 1.33 & 0.106 & $2,464,981$ \\
\hline & Hamburg-Lübeck & National (Germany) & 2 & 3959 & 68 & 1.25 & 0.090 & $3,759,739$ \\
\hline & Murcia-Alicante & National (Spain) & 2 & 2997 & 80 & 1.25 & 0.058 & $2,389,141$ \\
\hline & Ruoen-Le Havre & National (France) & 2 & 3502 & 83 & 1.00 & 0.050 & $1,492,658$ \\
\hline & Marseille-Toulon & National (France) & 2 & 1856 & 60 & 1.25 & 0.048 & $2,266,451$ \\
\hline
\end{tabular}


Table 2. Detailed list of classified nodes, which are not part of any territorial region beyond the metropolitane area and hinterland (Category E-F); arranged by quantity of nodes per country.

\begin{tabular}{|c|c|c|c|c|c|}
\hline Category & Classified Nodes & Country (No. of Nodes) & Category & Classified Nodes & Country (No. of Nodes) \\
\hline \multirow{22}{*}{ E } & $\begin{array}{l}\text { Paris, Montpellier, Caen, Tours, Clermont-Ferrand, } \\
\text { Orleans, Dijon, Troyes, Reims }\end{array}$ & France (9) & \multirow{22}{*}{$\mathrm{F}$} & $\begin{array}{l}\text { Lviv, Schytomyr, Winnyzja, Kiev, } \\
\text { Tschernihiw, Poltawa, Carkiw, } \\
\text { Dnipropetrowsk, Sapoischschja }\end{array}$ & Ukraine (9) \\
\hline & $\begin{array}{c}\text { Dresden, Nuernberg, Berlin, Bremen, Oldenburg, } \\
\text { Magdeburg, Kassel }\end{array}$ & Germany (7) & & $\begin{array}{l}\text { Brest, Nantes, Bordeaux, Toulouse, } \\
\text { Rennes, Le Mans }\end{array}$ & France (6) \\
\hline & $\begin{array}{c}\text { Northhampton, Bournemouth, Hull, Aberdeen, } \\
\text { Dundee }\end{array}$ & UK (5) & & $\begin{array}{l}\text { Wladimir, Pensa, Tambow, } \\
\text { Woronesch, Krasnodar }\end{array}$ & Russia (5) \\
\hline & Moscow, Rostow, Tula, Taganrog & Russia (4) & & $\begin{array}{l}\text { Temeswar, Cluj-Napoca, Bucharest, } \\
\text { Konstanza }\end{array}$ & Romania (4) \\
\hline & Warzaw, Lodz, Teschenstochau, Radom & Poland (4) & & Wroclaw, Posen, Bydgoszcz, Lublin & Poland (4) \\
\hline & Donezk, Luhansk & Ukraine (2) & & Bari, Catania, Palermo, Cagliari & Italy (4) \\
\hline & Valencia & Spain (1) & & Saragossa, Madrid, Seville & Spain (3) \\
\hline & Kopenhagen & Denmark (1) & & Minsk, Wizebsk, Homel & Belarus (3) \\
\hline & Budapest & Hungary (1) & & Stockholm, Gothenburg & Sweden (2) \\
\hline & Ljubljana & Slovenia (1) & & Prague, Brno & Czech Republic (2) \\
\hline & Grenoble & Switzerland (1) & & Sofia, Plowdiw & Bulgaria (2) \\
\hline & Rome & Italy (1) & & Athens, Thessaloniki & Greece (2) \\
\hline & Malmoe & Sweden (1) & & Riga & Latvia (1) \\
\hline & \multirow[t]{9}{*}{ Bratislava } & Slovakia (1) & & Belgrad & Serbia (1) \\
\hline & & & & Debrecen & Hungary (1) \\
\hline & & & & Kaunas & Lithuania (1) \\
\hline & & & & Cork & Ireland (1) \\
\hline & & & & Plymouth & UK (1) \\
\hline & & & & Graz & Austria (1) \\
\hline & & & & Oslo & Norway (1) \\
\hline & & & & Zagreb & Croatia (1) \\
\hline & & & & Tirana & Albania (1) \\
\hline
\end{tabular}




\subsubsection{Spatial Mapping of Territorial Regions}

Although the previous analysis (spanning soft spaces by measuring maximum connectivity based on the conjugation lines between nodes) indicates that large spatial conceptions such as the Blue Banana are reconstructued by settlement density, they are not reconstructed as a territorially bounded entity. Applying our region-growing approach originating from the connected nodes, we delimit territorial regions by settlement density. Applying this methodology we detect 22 regions (Cat. A-D) and 39 monocentric city regions (Cat. E) across Europe, which cover $2.96 \%$ of Europe's land surface . The delimited regions themselves feature very different constitutions: we identify one transnational, very large mega-region (Cat. A) with highest measures of the four variables across Europe (e.g., highest number of nodes); three large mega-regions (Cat. B) with measures for the four variables significantly lower than Category A; three large regions of cities featuring 3 to 6 nodes (Cat. C) and 15 small regions of cities with a maximum of 3 nodes (Cat. D). Overall, we find that nine out of 22 identified regions (Cat. A-D) are transnational spatial entities proving that national borders in Europe are not an obstacle.

Picking up the soft space constructed by the connected nodes strechting from central England to northern Italy which is dominating Europe's settlement pattern, the delimited territorial entites do not identify this as one territorial region. However, Europe's six largest regions and 14 out 22 identified regions (Cat. A-D) overall are tied to this network of nodes. They add up to $71.7 \%$ spatial share of all mapped regions across Europe; relative to Europe's land surface area, these territories connected to this backbone cover 2,12\%. Moreover, compared to the coarse constructed Blue Banana, we find this corridor highly variable in terms of width and spatial arragements along its path.

Europe's most dominating region is the transnational Randstaad-Ruhr-Cologne-Lille mega-region (Cat. A). With 37 identified nodes, high spatial concentration of nodes, high connectivity, and a territorial expansion more than twice as large as the second largest region (the Turin-Milan-Venice region in northern Italy), this mega-region reveals a lifted special role. This large mega-region houses more than 51 million inhabitants, $10 \%$ of the entire population of Europe (compare Table 1 for spatial and population details).

The three Category B mega-regions are, compared to the Randstaad-Ruhr-Cologne-Lille mega-region, significantly smaller entities; however, these regions still consist of a large number of nodes constructing large ploycentric urban patterns far beyond conceptions of individual cities: the London (12) dominated region, the area strechting from Cardiff via Birmingham to Liverpool and Leeds (17) as well as the region in northern Italy (9). Their significance is also shown that their population ranges between 21 and 24 million inhabitants.

The three Category $C$ regions consist of areas of three to six nodes and, in comparison to Category A and B, significant smaller populations (between 5 to 13 million inhabitants). However, as example, the delimited transnational region streching from Frankfurt via Wiesbaden, Mannheim, Karlsruhe, Stuttgart and to Straßburg, combining financial and industrial centers and providing a living environment for 13 million inhabitants is a core region in Central Europe. Finally, the Category D group of regions features only two to three nodes (ranging between 1.2. and 9 million inhabitants). Still most of these categories are located in Western or Central Europe.

\subsection{Plausibilization and Classification of the Results}

Is the proxy 'settlement pattern'-especially as the new GUF data feature higher geometric resolutions with superior accuracy-reasonable to detect relevant urban nodes, non-territorial soft spaces as well as territorial metropolitan focal regions? Taking the complexity of a multitude of possible regional logics introduced above into account, it becomes clear that an accuracy assessment in its original sense is not reasonable. Instead we compare the non-territorial and the territorial results to related data sets from other studies to assess the plausibility of this proxy and the related methodological approach. 
Starting with the identified nodes, the urban-rural typology confirms the expectation that a large share of our identified nodes $(65 \%)$ corresponds to the predominantly urban class and $32 \%$ fall into the intermediate class. The $2.6 \%$ of nodes spatially located in predominantly rural area are related to administrative specifics indicating a rural environment in areas where a de facto city is. All of those five nodes are located in either Ireland (1) or France (4) where the NUTS-3 regions used for the classification are significantly larger in size than in other countries (e.g., Germany or The Netherlands) due to administrative differences. Taking into account that the classification is based on the share of the rural population [67], it becomes more unlikely for a NUTS-3 entity to be classified as predominantly urban or intermediate in these specific regions and explains the deviation from our expectation.

Using another data set (the Urban Audit Cities) for plausibilization, we find within a search radius of $5 \mathrm{~km}$ from our detected nodes in $89 \%$ of all cases the center of an UAC. If we extend the search radius to $25 \mathrm{~km}, 100 \%$ confirmation is revealed. Overall, those numbers confirm the capability of the proxy 'settlement pattern' to identify urban nodes of relevance (Figure 5).

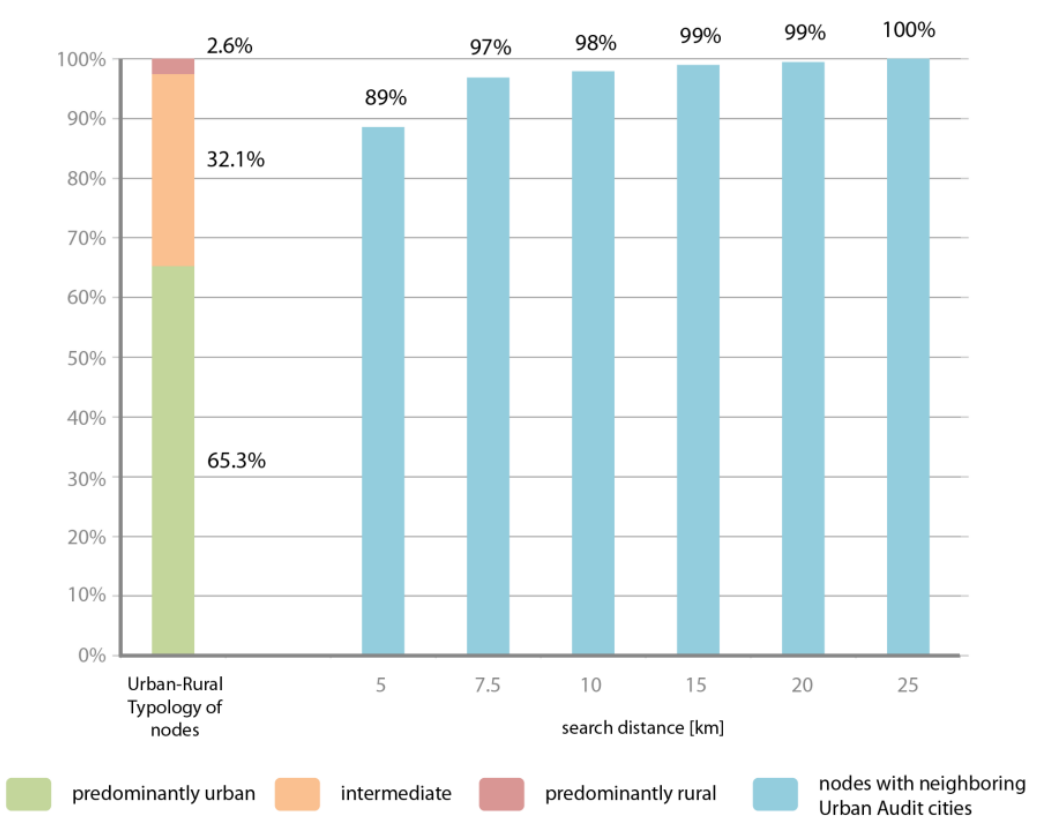

Figure 5. Plausibilization of detected nodes in relation to the Urban-Rural Typology and Urban Audit cities.

As the delimitation of regions relates to high settlement density we expect the population in the mapped areas to have a higher share than the settlement share. Overall this hypothesis is met as the detected regions feature only $43.5 \%$ of all settlement areas in Europe, but house $49 \%$ of the population. As examples, the London dominated region features only $2.8 \%$ of settlement area, but houses $4.1 \%$ of the population indicating urban concentration. Furthermore, it seems reasonable that the smallest region identified still consists of more than 1.2 million inhabitants (Figure 6). When we relate population not to settlement shares but to classified regional extents, the $49 \%$ of Europes' population are living at only $2.96 \%$ of the entire area of Europe. 
settlement area

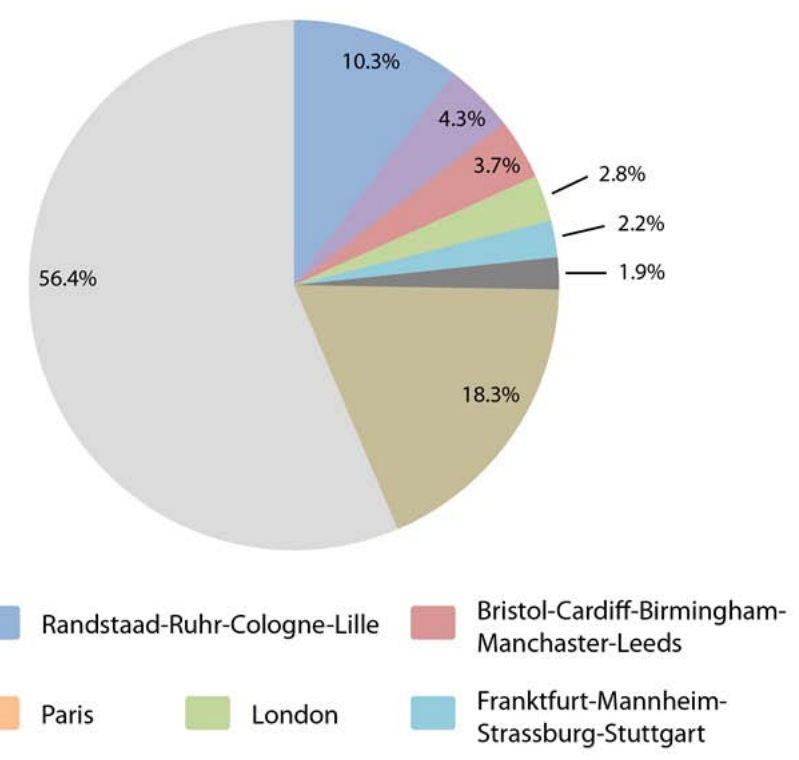

population

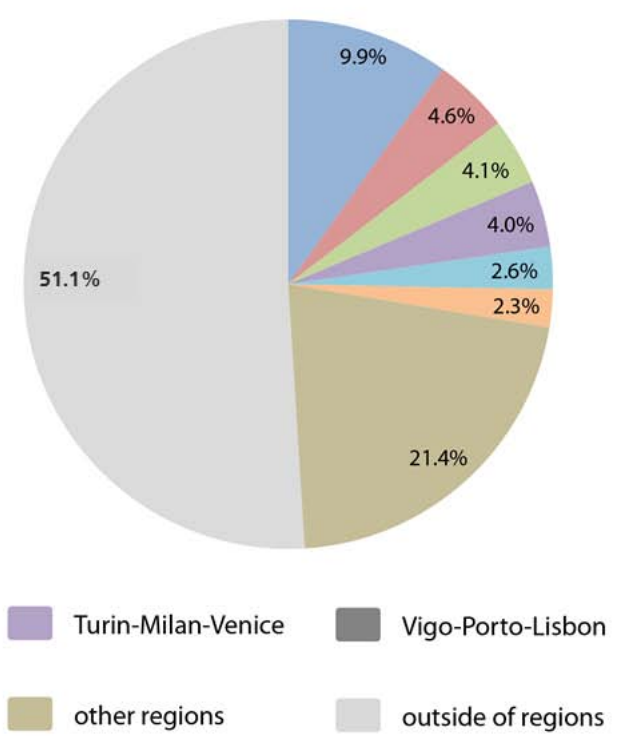

Figure 6. Plausibilization of delimited regions by comparison to their population distributions.

Furthermore, our approach using settlement density as proxy spatially corresponds well with many other related studies constructing regions. For example, the European Spatial Development Perspective (ESDP) 'Pentagon' [68] spanned by a polygon over London, Hamburg, Munich, Milan and Paris spatially corresponds to the core strech of unterritorial (with additional extensions in our approach towards France) regions. Our classification also detects all eight chosen focus regions within the POLYNET project [9]—South East England, The Randstaad, Central Belgium, Rhine-Ruhr, Rhine-Main, Northern Switzerland, Paris and Greater Dublin. However, not all of them are distinct regions in our approach, as The Randstaad, Central Belgium and Rhine-Ruhr have been delimited territorially within one large mega-region. Beyond, the 'Four motors of Europe' (Baden-Württemberg, Catalonia, Lombardy, Rhone-Alps) [23] have been detected by our settlement patterns approach.

In the studies of $[8,69]$ urban corridors and mega-regions have been delineated using a different EO data set-night-time lights imagery. The general pattern of distinct regions closely relates to the pattern identified using the GUF settlement pattern (compare Figure 6 in the paper of Florida et al. [69] and selected examples in Figure 7d). For instance, the Karslruhe-Vienna, Vienna-Bratislava-Budapest-Krakow as well as the Lisbon-Vigo corridors find spatial equivalents in our approach. However, differences to their studies exist as, e.g., our approach does not suggest the region in Italy streching from Milan to Naples and even further South.

As discussed above, settlement pattern reconstruct and extend the Blue, Yellow and Sunbelt Banana conceptions (Figure $7 \mathrm{~b}$ ) and even reconstruct the basic shape of the constructed space of the 'red octopus' (Figure 7c). Thus, this proxy indirectly carries information on socio-economic parameters, e.g., as the Blue Banana has higher per capita income and lower unemployment rates than the rest of Europe [66].

Overall, these quantitative and qualitative comparisons to other approaches (using other data, methods and conceptions) reveal that settlement pattern are a plausible proxy allowing us to detect and to re-construct nodes, soft spaces spanned by their connections and territorial regions. Due to their high resolution and accuracy the data set even holds potential to refine coarser spatial conceptions and detect new developments. 

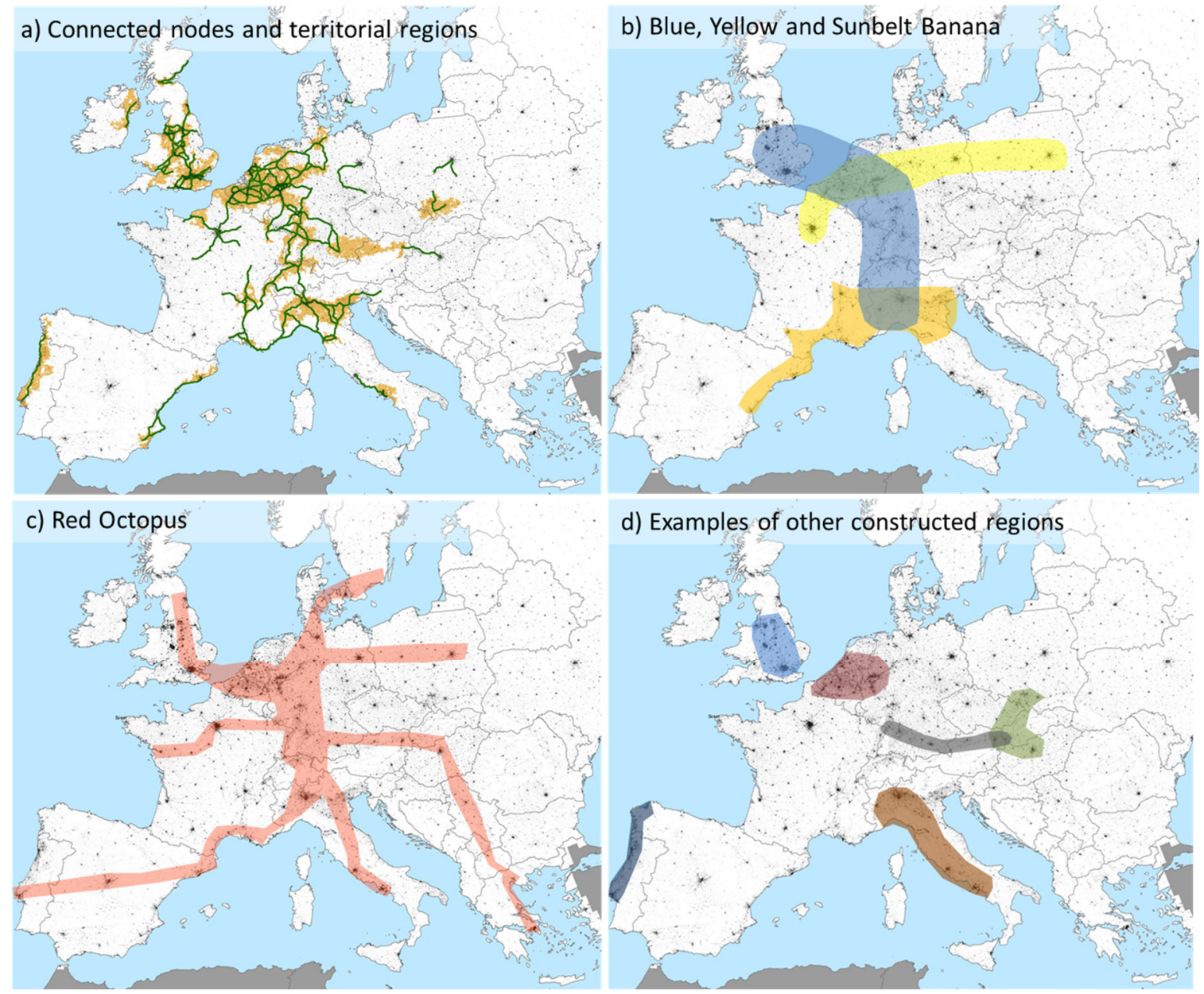

d) Examples of other constructed regions

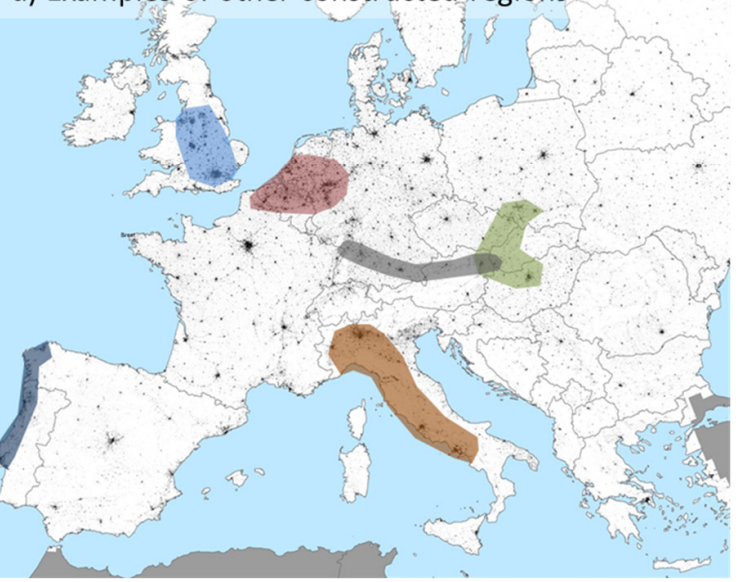

Figure 7. Constructed European regions: (a) Conjugation lines between nodes classified as connected (based on settlement contiguity) spanning soft spaces as well as related territorial regions based on on region-growing around nodes using settlement density-as used in this study and shown in Figures 2 and 3; (b) The 'Blue Banana' [17], the 'Yellow Banana' (e.g., [22]) and the 'Sumbelt Banana' [18] spatially conceptualized by economic developments; (c) the 'Red Octopus' [19] spatially conceptualized by economic developments; (d) Examples of constructed regions: brown (Milan-Rome-Naples), light blue (London-Leeds) [16] using economic developments, dark blue (Lisbon-Vigo), green (Vienna-Bratislava-Budapest-Krakow) [69], grey (Karlsruhe-Vienna) [8] using night-time lights; red (Ruhr-Randstaad) identified as mega-region by any data set (e.g. [14,69].

\section{Discussion}

This study makes clear that there is not only one regional logic, nor is there just a single dimension defining regional phenomena, nor is a constructed territorial or relational space 'correct' or 'incorrect' in absolute measures. As Dicken [70] discusses, regional phenomena are not a single, unified phenomena, but a syndrome of processes and activities. There is not one single 'driver', but a supercomplex series of multicentric, multiscalar, multitemporal, multiform and multicausal processes. Thus, we understand that it is increasingly different combinations of these elements that construct today's multitudes of 'new regional worlds' [4], forming spaces that complement, compete, or even contradict each other.

In our study, we approach regional phenomena using the characteristics of settlement pattern dervied from remote sensing data (following the space of place logic). We believe the GUF allows with its area-wide, consistent geodata an unbiased perspective on regional phenomena; as territories develop alongside, rather than replacing, existing forms of state scalar organizations [23], the data allow us to overcome artificial effects caused by admimistrative units. 
We are aware that the results may have consecutive errors as the GUF data contain classification errors. However, the study of Klotz et al. [34] reveals the improvement of this data sets over previous data sets on settlement pattern (e.g., in geometric resolution over MODIS or night-time lights) and in spatial coverage (e.g., compared to the European Urban Atlas), and thus allowing a spatially more detailed and complete perspective. Of course, this physical origin does not directly account for, as Castells [24] names it, the "space of flows" analyzing, e.g., socio-economic or political ties, as relationsships across space cannot be mapped in a territorial sense. Academics advocating for relational approaches (e.g., [71]) generally question the usefulness of representing regions as 'territorially fixed in any essential sense'. Moreover, in relation to this, continuous settlements are not necessarily essential along corridors, rather it is a possible result of their growth [16]. However, we found that settlement density is a well-founded proxy to account for reasonable territorial as well as non-terroitorial spaces.

With our triad of methodological approaches, we first identify nodes (by density and size). These are seen as crucial in space of flow conceptions. Secondly, these nodes set the basis to span unterritorial soft spaces (by continuous settlement), such as corridor conceptions like the Blue Banana. Thus, these two elements allow for a broader perspective beyond territorial space. Thirdly, we capture territorial regions (by settlement density around nodes). The results reveal spatial similarities to other studies (such as mega-regions or urban corridors).

For classifications we relied on the development of thresholds using existing data sets for more obvious decisions. While the thresholds chosen are of course at risk to be subjective, the plausibility check allows a positive evaluation as we find reasonable results when compared to similar studies. However, this is not the only point; the thresholds will likely not serve as a blueprint, but they allow for a consistent comparative urban research across the whole of Europe. With it, we encounter Europe as multiscale patchwork of territories of soft boundaries (by nodes and their spatial interconnectivity) and fixed territories (by density) at a spatially global-local interface. Thus, we believe settlement density is a relevant visual appearance of these underlying processes and allows us to construct regional phenomena. As mentioned, the applied thresholds are at risk to be subjective and, the thresholds in our approach are adjusted to fit the settlement patterns of the European continent. The workflow and data intrinsically allow a transfer to any area across the globe; however, while the adoption of the suggested thresholds will allow consistent comparative research, it needs to be evaluated if the thresholds are appropriate for the specific settlement patterns of other areas.

Geographically our study illustrates that regional disparities in Europe are still enormous and are conflicting the idea of a balanced economic growth and territorial equilibrium. While it was prefigured that advances in technology and communication would induce an era of global deconcentration and a diminishing role of cities in globalization [23], we still find a convergence of cities in ever-more large and complex polycentric concentrations of settlements. The European backbone is still strechting along the Blue Banana corridor in Central and Western Europe. However, we find new detours from this shape indicating new development axes especially to the East. The settlement patterns show that city networks and their resulting settlement pattern do not stop at national borders, thus form themsevles at a new, transnational scale. Illustrating this spatial process of convergence and connectivity at this new scale, the EO-data may support realizing, defining and accepting a new (urban) regionalism.

Settlement patterns are set in stone, and thus this approach carries old and new geographies of production, distribution and consumption. We are aware that they get continuosly disrupted and new physical and networked geographies are created. However, the plausibility of the approach shows how long-term structures continue to be important to the present day. From here on, additional studies consistently analyzing the changing pattern over time and the capabilities of EO-data to resolve urban land cover in distinctive socio-spatial articulations (e.g., analysis on block level) are demanded. With our multi-scale approach of nodes, connections and regions we approached the struggle to construct regions as both territorial as well as bounded but unterritorial map representations to account for the multitude of perspectives on spaces. 


\section{Conclusions}

Urbanization, effects of transportation networks and globalization, among other processes, are driving forces of global change, resulting in the emergence of new landscapes [35]. In consequence, planners and policy makers are in growing need of new significant data and scientific knowledge.

Remote sensing started to become one of the most relevant data sources and tools for capturing physical urban change (e.g., [51,69,72]) and analyzing patterns and structures (e.g., [73-77]) of these developing new landscapes. The latest EO-data set on settlement patterns-the Global Urban Footprint-is one significant new data set meeting the desire as formulated by Harrison [4] for more grounded and empirical research for interpreting regions. It provides spatially more detailed and highly accurate geoinformation freed from any administrative limitations. The settlement patterns are the visual appearance of urban concentration and prove to be a valuable proxy for the identification and construction of new regional phenomena. Especially in times when national boundaries become more and more permeable (or political developments may reverse this process again), new internationally significant territories of economic dynamism-named fundamental building blocks of a globally interconnected modern world [78] — are created [6]. These EO data sets have the capability to contribute to a more complete geographic understanding of regions and as we superimpose the concentration of settlements on the political geography, we find established national boundaries challenged. Although this is basically a single perspective representing the space of place, we believe it also allows a broader perspective beyond the territorial space.

In addition, we must acknowledge that this can only be another step that needs to be analysed alongside or in combination with new data from other disciplines to understand regional phenomena. This study may now function as one further basis for a more complete geographic understanding of regions that integrate both, the place and the flow of space at the same time [31]. Thus, we plea for multidisciplinary studies in the future combining our geoinformation with other data sources.

As we stated in the introdcution, in maps space is constructed. We aimed at giving a perspective on regional similarities and differences across the whole European continent using settlement pattern. With this construction of space uneven developments at fine scales can be mapped. We see this as a starting point for the demand for more comprehensive, empirical studies using other new data sets.

Acknowledgments: We thank the three anonymous reviewers for their valuable comments that helped to significantly improve the manuscript.

Author Contributions: Hannes Taubenböck was responsible for the research design, the conceptual framework, the data analyses and he wrote the initial manuscript. Joachim Ferstl performed the data analyses and visualizations, and contributed to the conceptual framework. Stefan Dech contributed to the research design and the conceptual framework. All authors discussed the results and commented the manuscript at all stages.

Conflicts of Interest: The authors declare no conflict of interest. The founding sponsors had no role in the design of the study, the data collection, the analyses, the interpretation of results, the process of writing of the manuscript or the decision to publish the results.

\section{References}

1. Storper, M. Justice, efficiency and economic geography: Should places help one another to develop? Eur. Urban Reg. Stud. 2011, 18, 3-21. [CrossRef]

2. Keating, M. The New Regionalism in Western Europe: Teritorial Restructuring and Political Change; Edward Elgar: Aldershot, UK, 1998.

3. MacLeod, G. New regionalism reconsidered: Globalization and the remaking of political economic space. Int. J. Urban Reg. Res. 2001, 25, 804-829. [CrossRef]

4. Harrison, J. Configuring the new 'regional world': On being caught between territory and networks. Reg. Stud. 2013, 47, 56-74. [CrossRef]

5. Ohmae, K. The End of the Nation State: The Rise of Regional Economies; Harper Collins: London, UK, 1995.

6. Deas, I.; Lord, A. From a new regionalism to an unusual regionalism? The emergence of non-standard regional spaces and lessons for the territorial reorgansation of the state. Urban Stud. 2006, 41, 1847-1877. [CrossRef] 
7. Florida, R. The Rise of the Creative Class—Revisited; Basic Books: New York, NY, USA, 2014.

8. Georg, I.; Blaschke, T.; Taubenböck, H. A global inventory of urban corridors based on perceptions and night-time light imagery. ISPRS Int. J. Geo-Inf. 2016, 5, 1-19. [CrossRef]

9. The Polycentric Metropolis: Learning from Mega-City-Regions in Europe; Hall, P.; Pain, K. (Eds.) Earthscan: London, UK, 2006.

10. Harrison, J.; Hoyler, M. Megaregions: Foundations, frailties, futures. In Megaregions: Globalization's New Urban Form? Harrison, J., Hoyler, M., Eds.; Edward Elgar Publishing Inc.: Northampton, MA, USA, 2015.

11. Pain, K. Spatial transformations of cities: Global city-region? Mega-city region? In International Handbook of Globalization and World Cities; Derudder, B., Hoyler, M., Taylor, P.J., Witlox, F., Eds.; Edward Elgar: Cheltenham, UK; Northampton, MA, USA, 2012; pp. 83-93.

12. Sassen, S. The Global City: New York, London, Tokyo; Princeton University Press: Princeton, NJ, USA, 1991.

13. Scott, A.J. Globalization and the rise of city-regions. Eur. Plan. Stud. 2001, 9, 813-826. [CrossRef]

14. Taubenböck, H.; Wiesner, M. The spatial network of megaregions-Types of connectivity between cities based on settlement patterns derived from EO-data. Comput. Environ. Urban Syst. 2015, 54, 165-180. [CrossRef]

15. Yang, J.; Song, G.; Lin, J. Measuring spatial structure of China's megaregions. J. Urban Plan. Dev. 2014. [CrossRef]

16. UN-Habitat. State of the World's Cities 2010/2011: Bridging the Urban Divide; Earthscan: London, UK; Sterling, VA, USA, 2008.

17. Brunet, R. Les Villes Europeennes. Report DATAR; La Documentation Francaise: Paris, France, 1989.

18. Dicken, P. Global Shift: Transforming the World Economy; Sage Publications Ltd.: London, UK, 1998.

19. Van der Meer, L. Red octopus. In A New Perspective for European Spatial Development Policies; Blass, W., Ed.; Ashgate: Aldershot, UK, 1998; pp. 9-19.

20. Institut D'Amenagement Et D'Urbanisme de la Region D'Ile-De-Frane (IAURIF). La Charte de L'Ille-de-France; IAURIF: Paris, France, 1991.

21. Nijkamp, P. Towards a network of regions: The United States of Europe. Eur. Plan. Stud. 1993, 1, 149-168. [CrossRef]

22. Hospers, G.J. Beyond the blue banana? Structural change in Europe's Geo-Economy. In Proceedings of the ERSA 2002-42nd Congress of the European Regional Science Association, Dortmund, Germany, 27-31 August 2002; pp. 76-85.

23. Harrison, J.; Growe, A. From places to flows? Planning for the new 'regional world' in Germany. Eur. Urban Reg. Stud. 2014, 21, 22-41. [CrossRef]

24. Castells, M. Grassrooting the space of flows. Urban Geogr. 1999, 20, 294-302. [CrossRef]

25. Amin, A. Regional unbound: Towards a new politics of place. Geografiska Annaler 2004, 86B, 33-44. [CrossRef]

26. Jessop, B.; Brenner, N.; Jones, M. Theorizing sociospatial relations. Environ. Plan. D 2008, 26, 389-401. [CrossRef]

27. Harrison, J. Networks of connectivity, territorial fragmentation, uneven development: The new politics of city-regionalism. Polit. Geogr. 2010, 29, 17-27. [CrossRef]

28. Jones, M.; MacLeod, G. Territorial/relational: Conceptualizing spatial economic governance. In Handbook of the Local and Regional Economic Development; Pike, A., Rodríguez-Pose, A., Tomaney, J., Eds.; Routledge: London, UK, 2010; pp. 259-271.

29. Hudson, R. Regions and regional uneven development forever? Some reflective common upon theory and practice. Reg. Stud. 2007, 41, 1149-1160. [CrossRef]

30. Jonas, A.E.G. Region and place: Regionalism in question. Prog. Hum. Geogr. 2012, 36, 263-272. [CrossRef]

31. Taylor, P.J. World City Network: A Global Urban Analysis; Routledge: New York, NY, USA, 2004.

32. Brenner, N. New State Space-Urban Governance and the Rescaling of Statehood; Oxford University Press: Oxford, UK, 2004.

33. Esch, T.; Taubenböck, H.; Roth, A.; Heldens, W.; Felbier, A.; Thiel, M.; Schmidt, M.; Müller, M.; Müller, A.; Dech, S. TanDEM-X mission: New perspectives for the inventory and monitoring of global settlement patterns. J. Sel. Top. Appl. Earth Observ. 2012, 6, 061702. [CrossRef]

34. Klotz, M.; Kemper, T.; Geiß, C.; Esch, T.; Taubenböck, H. How good is the map? A multi-scale cross-comparison framework for global settlement layers: Evidence from Central Europe. Remote Sens. Environ. 2016, 178, 191-212. [CrossRef] 
35. Antrop, M. Landscape change and the urbanization process in Europe. Landsc. Urban Plan. 2004, 67, 9-26. [CrossRef]

36. Dijkstra, L.; Poelman, H. A Harmonised Definition of Cities and Rural Areas: The New Degree of Urbanisation; Regional Working Paper 2014; Regional and Urban Policy, European Commission: Brussels, Belgium, 2012.

37. Taubenböck, H.; Wiesner, M.; Felbier, A.; Marconcini, M.; Esch, T.; Dech, S. New dimensions of urban landscapes: The spatio-temporal evolution from a polynuclei area to a mega-region based on remote sensing data. Appl. Geogr. 2014, 47, 137-153. [CrossRef]

38. Agnew, J.A. Arguing with regions. Reg. Stud. 2013, 47, 6-17. [CrossRef]

39. Ross, C.L.; Barringer, J.; Yang, J.; Woo, M.; Danner, A.; West, H.; Amekudzi, A.; Meyer, M. Megaregions: Delineating Existing and Emerging Megaregions. Center for Quality Growth and Regional Development (CQGRD) of Georgia Institute of Technology; Prepared for the U.S. Department of Transportation; Federal Highway Administration: Washington, DC, USA, 2009.

40. Glaeser, E. Triumph of the City; Penguin Books: London, UK, 2010.

41. Krehl, A.; Siedentop, S.; Taubenböck, H.; Wurm, M. A comprehensive view on urban spatial structure: urban density patterns of German city regions. ISPRS Int. J. Geo-Inf. 2016, 5, 1-21. [CrossRef]

42. Taubenböck, H.; Standfuß, I.; Wurm, M.; Krehl, A.; Siedentop, S. Measuring morphological polycentricity-A comparative analysis of urban mass concentrations using remote sensing data. Comput. Environ. Urban Syst. 2017, 64, 42-56. [CrossRef]

43. United Nations. The 2014 Revision; Population Division; Department of Economic Affairs, United Nations Publications: New York, NY, USA, 2014.

44. Parr, J.B. Perspectives on the city-region. Reg. Stud. 2005, 39, 555-566. [CrossRef]

45. Prytherch, D.L. 'Vertebrating' the region as a networked space of flows: Learning from the grammar of Catalanist territoriality. Environ. Plan. A 2010, 42, 1537-1544. [CrossRef]

46. United Nations Center for Human Settlement. An Urbanizing World. 1996. Available online: http:/ / mirror. unhabitat.org/pmss/listItemDetails.aspx?publicationID=1650\&AspxAutoDetectCookieSupport=1 (accessed on 17 February 2017).

47. Batten, D.F. Network cities: Creative urban agglomerations for the 21st century. Urban Stud. 1995, 32, 313-327. [CrossRef]

48. Ross, C.L. Literature Review of Organizational Structures and Finance of Multi-jurisdictional Initiatives and the Implications for Megaregion Transportation Planning in the U.S. 2011. Available online: http:/ / www.fhwa.dot.gov/planning/publications/megaregions_report_2012/megaregions2012.pdf (accessed on 17 February 2017).

49. Haughton, G.; Allmendinger, P.; Counsell, D.; Vigar, G. The New Spatial Planning: Territorial Management with Soft Spaces and Fuzzy Boundaries; Routledge: London, UK, 2010.

50. Pesaresi, M.; Huadong, G.; Blaes, X.; Ehrlich, D.; Ferri, S.; Gueguen, L.; Halika, M.; Kauffmann, M.; Kemper, T.; Lu, L.; et al. A global human settlement layer from optical HR/VHR RS data: Concept and first re-sults. IEEE J. Sel. Top. Appl. Earth Obs. Remote Sens. 2013, 6, 2102-2131. [CrossRef]

51. Taubenböck, H.; Esch, T.; Felbier, A.; Wiesner, M.; Roth, A.; Dech, S. Monitoring of mega cities from space. Remote Sens. Environ. 2012, 117, 162-176. [CrossRef]

52. Schneider, A.; Friedl, M.; Potere, D. Mapping global urban areas using MODIS 500-M data: New methods and datasets based on 'urban ecoregions'. Remote Sens. Environ. 2010, 114, 1733-1746. [CrossRef]

53. ESA-European Space Agency. Globcover 2009_Product Description and Validation Report. European Space Agency (ESA). 2009. Available online: https://globcover.s3.amazonaws.com/LandCover2009/ GLOBCOVER2009_Validation_Report_1.0.pdf (accessed on 8 November 2016).

54. Elvidge, C.D.; Hsu, F.C.; Baugh, K.E.; Gosh, T. National trends in satellite-observed lighting 1992-2012. In Global Urban Monitoring and Assessment through Earth Observation; Weng, Q., Ed.; CRC Press: Boca Raton, FL, USA, 2014; pp. 97-120.

55. EEA-European Environment Agency. Mapping Guide for a European Urban Atlas. 2016. Available online: http://www.eea.europa.eu/data-and-maps/data/urban-atlas/mapping-guide (accessed on 3 November 2016). 
56. Openshaw, S. The Modifiable Areal Unit Problem; Geo Books: Norwick, UK, 1983.

57. EEA-European Environment Agency. Urban Morphological Zones. 2016. Available online: http://www. eea.europa.eu/data-and-maps/data/urban-morphological-zones-2006; http:/ ftp.eea.europa.eu/www/ umz/v4f0/RpD_UMZ_Methodology_f3.0.pdf (accessed on 17 February 2017).

58. Eurostat. 2015. Available online: http://ec.europa.eu/eurostat/web/nuts/local-administrative-units (accessed on 17 February 2017).

59. Eurostat Urban-Rural Typolog. 2016. Available online: http://ec.europa.eu/eurostat/statistics-explained/ index.php/Urban-rural_typology_update (accessed on 17 February 2017).

60. Eurostat Urban Audit Cities. 2016. Available online: http:/ /ec.europa.eu/eurostat/documents/4422005/ 6840613/RYB-2015-Annex2-Cities-CandK.pdf (accessed on 17 February 2017).

61. Bonin, O.; Baro, J.; Hubert, J.-P. Technological innovation: Identification of urban structures on regular quared grids with the help of spatial calculus. In Proceedings of the IGU Urban Commission Annual Conference, University College Dublin, Ireland, 6-11 August 2015; Available online: http://www.unil.ch/igu-urban/files/live/sites/igu-urban/files/IGU/Pubications2016/IGU\% 20Dublin\%202015\%20Urban\%20challenges\%20in\%20a\%20complex\%20world.pdf\#page=109 (accessed on 17 February 2017).

62. Cheng, J.; Bertolini, L.; le Clerk, F.; Kapoen, L. Understanding urban networks: Comparing a node-, a densityand an accessibility-based view. Cities 2013, 31, 165-176. [CrossRef]

63. Eurostat Population distribution, 2016a. Available online: http://ec.europa.eu/eurostat/web/gisco/ geodata/reference-data/population-distribution-demography/geostat $\% 20$ - $\% 20$ geostat11 (accessed on 17 February 2017).

64. Jenks, G.F.; Caspall, F.C. Error on choroplethic maps. Definition, measurement, reduction. Ann. Assoc. Am. Geogr. 1971, 61, 217-244. [CrossRef]

65. Taubenböck, H.; Standfuß, I.; Klotz, M.; Wurm, M. The physical density of the city-Deconstruction of the delusive density measure with evidence from European megacities. ISPRS Int. J. Geo-Inf. 2016, 5, 1-24. [CrossRef]

66. Heidenreich, M. The changing system of European cities and regions. Eur. Plan. Stud. 1998, 6, 315-332. [CrossRef]

67. Eurostat. Eurostat Regional Yearbook 2012; Eurostat: Luxembourg, 2012.

68. ESPON. ESPON Project 1.1.1: The Role, Specific Situation and Potentials of Urban Areas as Nodes in a Polycentric Development; Final Version; Final Report; ESPON: Luxembourg, 31 March 2005; Available online: http://www.espon.lu/online/documentation/projects/thematic/1873/fr-1.1.1_revised.pdf (accessed on 8 November 2016).

69. Florida, R.; Gulden, T.; Mellander, C. The rise of the mega-region. Camb. J. Reg. Econ. Soc. 2008, 1, 459-476. [CrossRef]

70. Dicken, P. Global Shift: Mapping and Changing Contuors of the World Economy; Sage Publications Ltd.: London, UK, 2014.

71. Allen, J.; Cochrane, A. Beyond the territorial fix: Regional assemblages, politics and power. Reg. Stud. 2007, 41, 1161-1175. [CrossRef]

72. Angel, S.; Parent, J.; Civco, D.L.; Blei, A.M.; Potere, D. The dimensions of global urban expansion: Estimates and projections for all countries, 2000-2050. Prog. Plan. 2011, 75, 53-108. [CrossRef]

73. Frolking, S.; Milliman, T.; Seto, K.; Friedl, M.A. A global fingerprint of macro-scale changes in urban structure from 1999 to 2009. Environ. Res. Lett. 2013, 8, 10. [CrossRef]

74. Esch, T.; Marconcini, M.; Marmanis, D.; Zeidler, J.; Elsayed, S.; Metz, A.; Müller, A.; Dech, S. Dimensioning urbanization-An advanced procedure for characterizing human settlement properties and patterns using spatial network analysis. Appl. Geogr. 2014, 55, 212-228. [CrossRef]

75. Marull, J.; Font, C.; Boix, R. Modelling urban networks at mega-regional scale: Are increasingly complex urban systems sustainable? Land Use Policy 2015, 43, 15-27. [CrossRef]

76. Siedentop, S.; Fina, S. Who sprawls most? Exploring the patterns of urban growth across 26 European countries. Environ. Plan. A 2012, 44, 2765-2784. [CrossRef] 
77. Taubenböck, H.; Wegmann, M.; Roth, A.; Mehl, H.; Dech, S. Urbanization in India-Spatiotemporal analysis using remote sensing data. Comput. Environ. Urban Syst. 2009, 33, 179-188. [CrossRef]

78. Storper, M. The Regional World: Territorial Development in a Global Economy; Guildford: New York, NY, USA, 1997.

(c)

(C) 2017 by the authors. Licensee MDPI, Basel, Switzerland. This article is an open access article distributed under the terms and conditions of the Creative Commons Attribution (CC BY) license (http:/ / creativecommons.org/licenses/by/4.0/). 